\title{
Agronomic and physiological traits related to the genetic advance of semi- dwarf durum wheat: The case of Spain
}

\author{
Fadia Chairi $^{\mathrm{a}, \mathrm{b}}$, Rut Sanchez-Bragado ${ }^{\mathrm{b}, \mathrm{c}}$, Maria Dolores Serret ${ }^{\mathrm{a}, \mathrm{b}}$, Nieves Aparicio ${ }^{\mathrm{d}}$, \\ Maria Teresa Nieto-Taladriz ${ }^{\mathrm{e}}$, José Luis Araus ${ }^{\mathrm{a}, \mathrm{b}, *}$ \\ a Section of Plant Physiology, University of Barcelona, Barcelona, Spain \\ ${ }^{\mathrm{b}}$ AGROTECNIO (Center of Research in Agrotechnology), Lleida, Spain \\ ${ }^{\mathrm{c}}$ Department of Crop and Forest Sciences, University of Lleida, Lleida, Spain \\ d Instituto de Tecnología Agraria de Castilla y León (ITACyL), Valladolid, Spain \\ ${ }^{\mathrm{e}}$ Instituto Nacional de Investigación y Tecnología Agraria y Alimentaria (INIA), Madrid, Spain
}

\section{A R T I C L E I N F O}

\section{Keywords:}

Genetic gain

Durum wheat

Canopy temperature

Carbon isotope composition

Agronomic yield components

Physiological traits

\begin{abstract}
A B S T R A C T
Knowledge of the agronomic and physiological traits associated with genetic gains in yield is essential to improve understanding of yield-limiting factors and to inform future breeding strategies. The aim of this paper is to dissect the agronomic and physiological traits related to genetic gain and to propose an ideotype with high yield that is best adapted to Spanish Mediterranean environments. Six semi-dwarf (i.e. modern) durum wheat genotypes were grown in a wide range of growing conditions in Spain during two successive years. Diverse agronomic, physiological and leaf morphological traits were evaluated. Kernels spike ${ }^{-1}$ was the yield component most affected by the genetic gain. While no interaction between genotype and growing conditions existed for grain yield, the more productive genotypes were characterized by a plant height of around $85 \mathrm{~cm}$, small erect flag leaves, more open stomata, a better balance between $\mathrm{N}$ sources and $\mathrm{N}$ sinks and a higher capacity to re-fix $\mathrm{CO}_{2}$ respired by the grain. Moreover, in general the non-laminar parts of the plants play a key role in providing assimilates during grain filling. The high heritability of most of the studied parameters allows their consideration as traits for phenotyping durum wheat better adapted to a wide range of Mediterranean conditions.
\end{abstract}

\section{Introduction}

Durum wheat is the $10^{\text {th }}$ most important crop worldwide owing to its annual production of 37 million tons [1,2]. Moreover, it is one of the most widely cultivated herbaceous crops in the Mediterranean basin, where terminal abiotic stresses are the main yield constraints. Italy and Spain are the largest producers of durum wheat in the Mediterranean basin [3]. In Spain, durum wheat represents about 5.7\% (1.32 million tons) of the national cereal production, and about $65 \%$ of the area under durum wheat cultivation is located in the Southern part of the country (Andalucía) [4].

Increasing grain yield in cereal crops in general and durum wheat in particular has been a major goal of most breeding programs, and the effects of genetic improvement on yield potential have been reported in several studies [5-7]. The grain yield of durum wheat has increased significantly worldwide from the early 1960s, coinciding with the adoption of the green revolution. Spain has followed the same trend, with the average yield of $2.8 \mathrm{Mg} \mathrm{ha}^{-1}$ for pre-green revolution genotypes rising beyond $5 \mathrm{Mg} \mathrm{ha}^{-1}$ for varieties released in the 1980 s $[7,8]$. However, in the last three decades yield improvement for both durum and bread wheat has slowed, indicating that genetic gain is potentially leveling off $[7,9,10]$. Nevertheless, despite no clear advances in recent times, genotypic differences do exist in grain yield across the post green revolution durum wheat varieties released in Spain [7,11]. Dissecting the agronomic and physiological components behind the genotypic differences in grain yield may contribute towards genetic advances in future breeding.

The increase in yield during the green revolution, associated with the introduction of semi-dwarf (i.e. modern) cultivars, was mainly achieved by a decrease in plant height, thus reducing lodging, while increasing the harvest index, due to a reduced competition from the growing stem, resulting in larger spikes with more grains per spike [12]. However, further decreases in plant height do not seem feasible and in fact may penalize yield potential and even adaptation to

\footnotetext{
Abbreviations: CT, canopy temperature; $\delta^{13} \mathrm{C}$, carbon isotope composition; KWSP, kernel weight per spike; KNSP, total kernel nitrogen per spike; PH, plant height

* Corresponding author at: Section of Plant Physiology, University of Barcelona, Barcelona, Spain.

E-mail address: jaraus@ub.edu (J. Luis Araus).
} 
unfavorable conditions $[13,14]$. On the other hand, the green revolution was not associated with an increase in TKW, with the opposite occurring instead $[7,11]$, nor was there an increase in the number of spikes per square meter [7]. Moreover, the increase in grain yield associated with the green revolution does not seem to have been related to more biomass but rather its redistribution [11,15], despite the fact that some reports indicate higher biomass in more recent cultivars [16]. Genetic gain in grain yield may also be achieved through targeting additional traits closely associated with improved plant adaptation to stress [17]. Under water limiting conditions, various physiological processes and traits have been associated with GY [18-20]. Among them are traits related to delays in senescence (i.e. staygreen) during grain filling assessed via changes in leaf greenness [21,22]. Moreover, staygreen also appears to be beneficial in terms of increasing yield potential [22]. Senescence is a genetically programmed and environmentally influenced process resulting in the destruction of chlorophyll and the remobilization of nutrients to younger or reproductive parts of plants, and this is the case for growing grains in cereals [23]. It has been widely assumed that extending the green canopy duration by delaying senescence will extend the grain filling period, increase grain yield [24] and contribute to yield stability under stress [23]. Other traits like higher stomatal conductance have also been proposed as being associated with genetic advance in yield potential [25], as well as under moderate to medium stress conditions [26]. This is further supported by the positive phenotypic correlations usually found between yield and carbon isotope discrimination $\left(\Delta^{13} \mathrm{C}\right)$ or the negative correlations with carbon isotope composition $\left(\delta^{13} \mathrm{C}\right)$ within Mediterranean environments [19,27-31]. In wheat, $\Delta^{13} \mathrm{C}$ can provide an indirect determination of the effective water use of the crop [19,32]. Although a negative association between $\Delta^{13} \mathrm{C}$ and yield has been found under very dry Mediterranean rainfed conditions, a positive association is more common because genotypes capable of sustaining greater stomatal conductance and water consumption are more productive $[27,33]$. The carbon isotope signature has also been used to evaluate the relative contribution of different photosynthetic organs during grain filling [34-36]

In this study we dissected the agronomic and physiological traits related to genetic gain in durum wheat during recent decades. We have selected a subset of six representative cultivars from a set of 20 post green revolution cultivars studied by Chairi et al. [7]. In this previous study, and except for the number of kernels per spike, for the three decades studied there was no significant temporal trend in the genetic advance of yield or other agronomic (grain yield, grain weight and spikes per square meter) and phenological (e.g. days to heading) components, or physiological (egg. $\delta^{13} \mathrm{C}$ ) traits [7]. Also, we investigated the role of different plant parts as photosynthetic contributors during grain filling.

\section{Materials and methods}

\subsection{Plant material and growing conditions}

Experiments were carried out under field conditions in three experimental stations embracing a wide range of latitudes and elevations, therefore providing a wide range of growing temperatures in Spain. Experiments were conducted at the experimental stations of the Spanish "Instituto Nacional de Investigación y Tecnología Agraria y Alimentaria" (INIA) at Coria del Rio (Cor), Seville $\left(37^{\circ} 14^{\prime}\right.$ N. $06^{\circ} 03^{\prime}$ W. 5 masl) and Colmenar de Oreja-Aranjuez (Aran), Madrid $\left(40^{\circ} 04^{\prime} \mathrm{N}\right.$. $3^{\circ} 31^{`}$ W. 590 masl), as well as at the "Instituto Tecnológico Agrario de Castilla y León” (ITACyL) in Zamadueñas (Zam), Valladolid $\left(41^{\circ} 41^{\prime} \mathrm{N}\right.$. $04^{\circ} 42^{\prime} \mathrm{W}$. 700 masl). Trials were conducted during two successive crop seasons (2013-14, and 2014-15), except for Coria where only one trial was conducted during the second crop season (Table1).

Six durum wheat (Triticum turgidum L. subsp. Durum (Desf) Husn.) cultivars were selected among a set of 20 fully semi-dwarf (i.e. modern) cultivars, evaluated in a previous study and released in Spain during the three decades (1980-2009) after the green revolution [7]. Specific cultivars were chosen to be representative of variability in yield performance, including some extreme genotypes (with contrasting yield within trials), while maintaining similar phenology [7,37]: Sula (1994), Iride (1998), Pelayo (2002), Don Sebastian (2004), Don Ricardo (2008) and Kiko Nick (2009).

Plots were sown in a randomized block design with three replicates. Each plot consisted of six rows $7 \mathrm{~m}$ long and $0.2 \mathrm{~m}$ apart, with a planting density of 250 seeds $\mathrm{m}^{-2}$. Rainfed (RF) and supplemental irrigation (IR) conditions were imposed at Aran and Zam. Due to the presence of a shallow water table caused by proximity to the Guadalquivir River, genotypes could only be evaluated under rainfed conditions at the Cor experimental site. A different irrigation regime was applied at each site, with the timing and amount of water applied designed to ensure good crop growth during the critical period from stem elongation to mid grain filling. To that end, at each site specific agronomic practices were followed. For both years at Aranjuez (A1IR and A2IR), irrigation was applied to compensate for evapotranspiration during the period between stem elongation and the milk-dough development stage. For both years at Zamadueñas (Z1IR and Z2IR), $25 \mathrm{~mm}$ of irrigation was applied approximately every week from heading to ripening.

Considering location (Aran, Zam and Cor), water regime (RF and IR) and seasons (1 and 2), a total of nine growing conditions were evaluated, four in the first year and five in the second. Phenology was recorded throughout the crops life cycle using the Zadoks scale for growth stages (GS) [38]. Days to heading (days from emergence until $50 \%$ of the spikes are half emerged, GS55) were recorded in all environments. Plant height $(\mathrm{PH})$ was measured after anthesis as the distance from ground to the ear tip, excluding awns.

In the second year, together with $\mathrm{PH}$, leaf length, leaf width and spike length were measured. Flag leaf blade, ear and peduncle samples were taken at early grain filling (GS 71) and were saved at $-80^{\circ} \mathrm{C}$ for carbon isotope composition and elemental carbon and nitrogen analyses.

\subsection{Agronomic traits}

For each plot the number of spikes per $\mathrm{m}^{2}$ (spike $\mathrm{m}^{-2}$ ) was determined at maturity by sampling and counting the spikes contained in two 0.5 m-length portions of one of the central-rows at Zam and one $0.5 \mathrm{~m}$ length of a central-row at Cor and Aran. Further, kernels spike ${ }^{-1}$ was determined using a subset of ten representative stems per plot. GY was assessed by harvesting the whole plot. Then the thousand kernel weight (TKW) was measured and subsequently the number of kernels per $\mathrm{m}^{2}$ (kernels $\mathrm{m}^{-2}$ ) was determined, together with the total kernel weight (KWPS) and the total kernel nitrogen (KNSP) per spike.

\subsection{Remote sensing indices}

In the first-year remote sensing measurements were undertaken once, around early grain filling (GS71). In the second year, measurements were carried at around booting (GS 45), early grain filling (GS 71), medium grain filling (GS 75) and late grain filling (GS77). The normalized difference vegetation index (NDVI) was determined with a portable spectroradiometer with an active sensor (GreenSeeker handheld crop sensor, Trimble, USA) scanning with the sensor held perpendicularly to the canopy and $0.5-0.6 \mathrm{~m}$ above the top canopy. NDVI was calculated using the equation: NDVI $=(\mathrm{NIR}-\mathrm{R}) /(\mathrm{NIR}+\mathrm{R})$, where $R$ is the reflectance in the red band $(660 \mathrm{~nm})$ and NIR is the reflectance in the near-infrared band $(760 \mathrm{~nm})$.

One digital RGB picture was taken per plot, holding the camera at $0.8-1.0 \mathrm{~m}$ above the plant canopy, in a zenithal plane and focusing near the center of each plot. Photographs were taken with a Nikon D40 camera. The camera had a set focal length of $18 \mathrm{~mm}$, shutter speed of $1 /$ 


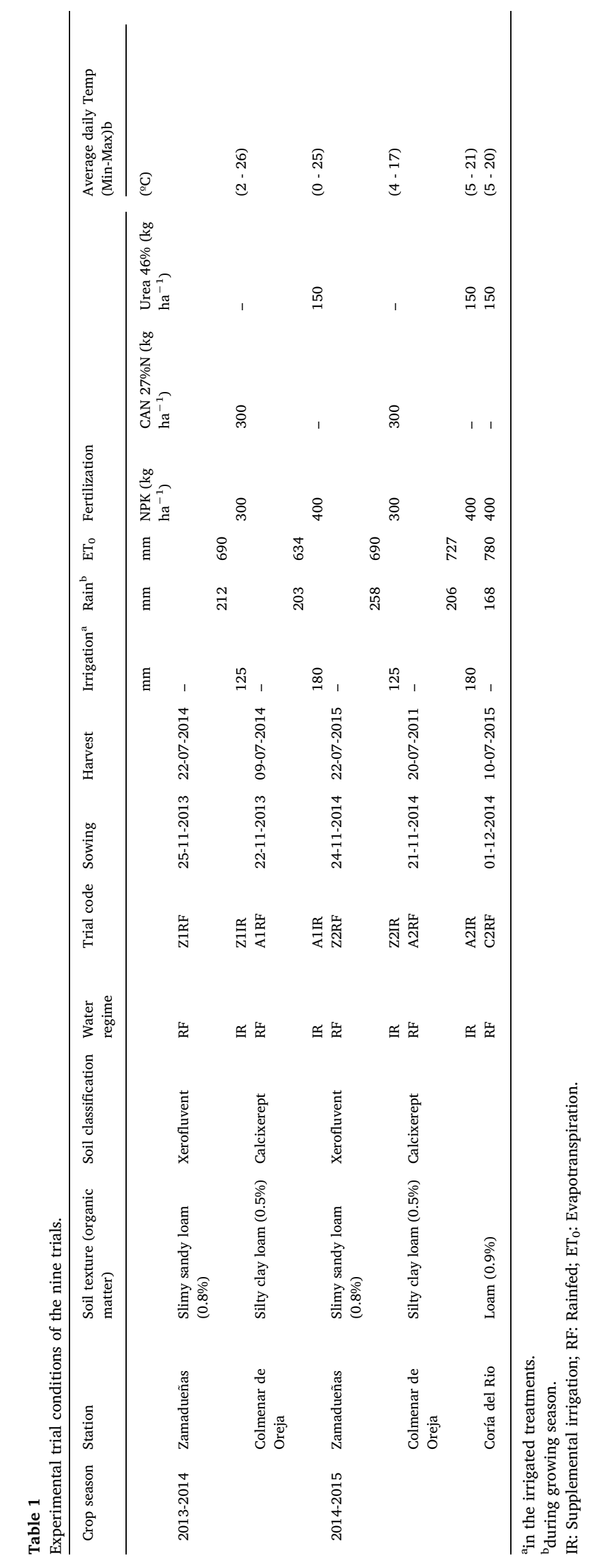


125 without flash, the aperture set to automatic and the images were saved in JPEG format with a size of $1920 \times 1280$ pixels. Pictures were subsequently analyzed with the open source Breedpix 0.2 software designed for digital photograph processing of different color properties [39]. This software enabled the determination of the RGB vegetation indices green area (GA) and greener area (GAA). Both are formulated based on the number of green pixels in the image, but differ due to GAA excluding yellowish-green tones and therefore more accurately describing the amount of photosynthetically active biomass and leaf senescence.

The leaf chlorophyll content (Leaf $\mathrm{Chl}$ ) was measured using a portable chlorophyll meter (SPAD-502 Chlorophyll Meter, Minolta Co. Ltd., Osaka, Japan). Five flag leaves were measured for each plot. Measurements were taken from the middle portion of the lamina.

\subsection{Total $N$ content and $C$ and $N$ isotope analyses}

For the first year, only mature kernels were analyzed. For the second year, together with mature kernels, the dry matter and water-soluble fraction in the flag leaf, peduncle and different ear parts (awns, glumes, lemma and palea) were analyzed. All the measurements were performed for each individual plot, within the entire set of trials.

Stable carbon $\left({ }^{13} \mathrm{C} /{ }^{12} \mathrm{C}\right)$ and nitrogen $\left({ }^{15} \mathrm{~N} /{ }^{14} \mathrm{~N}\right)$ isotope ratios, together with the total nitrogen content, were determined. Measurements of carbon and nitrogen isotopes were conducted at the Scientific Facilities of the University of Barcelona, using an elemental analyzer (Flash 1112 EA; Thermo Finnigan, Berman Germany) coupled with an isotope ratio mass spectrometer (Delta C IRMS, Thermo Finnigan), operating in continuous flow mode. Isotopic results were expressed in standard $\delta$-notation [40].

$X=\left(\frac{\text { Rsample }}{\text { Rstandard }}-1\right) \times 100$

where $\mathrm{X}$ is the $\delta^{13} \mathrm{C}$ or $\delta^{15} \mathrm{~N}$ value, and $\mathrm{R}$ is the ${ }^{13} \mathrm{C} /{ }^{12} \mathrm{C}$ or ${ }^{15} \mathrm{~N} /{ }^{14} \mathrm{~N}$ ratios, respectively. The $\delta^{13} \mathrm{C}$ values were reported relative to the Vienna PeeDee Belemnite standard, whereas the $\delta^{15} \mathrm{~N}$ values were reported relative to the standard $\mathrm{N}_{2}$ in air [41].

\subsection{Water soluble fraction}

The protein-free water-soluble fraction (WSF) of the flag leaves and ears was extracted from the same dry samples tested for carbon isotope composition, as described previously [42-44]. Leaf and ear powder were suspended with $1 \mathrm{ml}$ of Milli-Q water in an Eppendorf tube (Eppendorf Scientific, Hamburg. Germany). After centrifugation, the supernatant containing the WSF was collected. Soluble proteins in the supernatant were heat-denatured and precipitated. After centrifugation, an aliquot of $60 \mu \mathrm{l}$ of the supernatants containing the protein-free WSF was transferred to tin capsules and dried at $60{ }^{\circ} \mathrm{C}$ for isotope analyses as indicated above.

\subsection{Statistical analysis}

The hypothesis of zero difference between means was tested with analysis of variance (ANOVA) performed using the general linear model procedure to calculate first the effects of year, environment (combination of specific site $\mathrm{x}$ water regime), genotype and environment by genotype interactions on the measured and calculated parameters. Then, because the year effect was not significant for GY we combined the two-year data and analyzed the environment (combination of year $\mathrm{x}$ specific site $\mathrm{x}$ water regime) and genotype effects and their interaction. Mean separation between genotypes for the different parameters was performed with Duncan's multiple range test $(P<0.05)$. Broad sense heritability (h2) was estimated for each trait over the different environments as: $h^{2}=\frac{\sigma_{g}^{2}}{\sigma_{g}^{2}+\frac{\sigma_{g e}^{2}}{e}+\frac{\sigma^{2}}{r e}}$

where $r=$ number of repetitions, $e=$ number of environments, $r 2$ $=$ error variance, $\mathrm{r} 2 \mathrm{~g}=$ genotypic variance and $\mathrm{r} 2 \mathrm{ge}=\mathrm{G} \times \mathrm{E}$ variance. Calculations were done using either the subset of six genotypes or the original set of 20 genotypes [7].

A bivariate correlation procedure was constructed to analyze the relationships between the studied traits. Stepwise regression analyses were conducted with grain yield as the dependent variable and yield components as the independent ones. Data were analyzed using the SPSS 21.0 statistical package (SPSS Inc., Chicago, IL, USA). Figures were created using the Sigma-Plot 11.0 program for Windows (Systat Software Inc., Point Richmond, CA, USA). A principal component analysis (PCA) of yield components and physiological parameters of wheat were carried out in Rstudio version 3.4.3. In addition, yield stability of genotypes was assessed using the genotype main effects and genotype $\times$ environment interaction effect GGE biplot methodology, by an average environment coordinate (AEC) method [45] using GEA-R free software analysis [46] including the 20 genotypes evaluated in a previous study [7]. In this method, the average principal components were used for each of the nine growing conditions. A line was then drawn through this average environment and the biplot origin; this line is called the average environment axis and serves as the abscissa of the AEC. Unlike the AEC abscissa, this has one direction, with the arrow pointing to a greater genotype main effect; the AEC ordinate and either direction away from the biplot origin indicates a greater genotype $\mathrm{x}$ environment interaction (GEI) effect and reduced stability.

\section{Results}

\subsection{Grain yield and agronomic yield components}

GY across genotypes ranged between $5.96 \mathrm{Mg} \mathrm{ha}^{-1}$ (Pelayo) and $4.69 \mathrm{Mg} \mathrm{ha}^{-1}$ (Don Sebastian), considering the two crop seasons (nine growing conditions), with no significant year effect but significant genotypic variation (Table S1). When combining the two-year data, significant differences between both genotypes and growing conditions were found (Table 2). The same pattern of differences was found in the second year on its own (Table S2). In fact, Pelayo and Don Sebastian were the two extreme genotypes, when either the nine growing conditions or only the five growing conditions of the second season were considered. In addition, there were no differences across genotypes in days to heading (DTH).

Concerning the agronomic components, a significant year effect was observed for all traits, while the genotypic variation was also significant for all traits except biomass (BM) at maturity (Table S1). When combining the two-year data, all of the agronomic components exhibited genotypic variation except again BM. Thousand kernel weight (TKW) ranged from $49.95 \mathrm{~g}$ (Don Sebastian) to $41.60 \mathrm{~g}$ (Sula), kernels per spike (kernels spike ${ }^{-1}$ ) ranged from 41.37 (Iride) to 25.11 (Don Sebastian), spikes $\mathrm{m}^{-2}$ ranged from 404.3 (Kiko Nick) to 333.5 (Iride), kernels $\mathrm{m}^{-2}$ ranged from 10,392 (Don Sebastian) to 14,498 (Iride), KWPS ranged from $1.25 \mathrm{~g}$ (Don Sebastian) to $1.76 \mathrm{~g}$ (Iride) and HI ranged from 32.51 (Don Sebastian) to 41.93 (Iride). The two extreme genotypes in terms of grain yield exhibited different response patterns in their agronomic yield components (Table 2 and Table S2). Among the six genotypes studied, Don Sebastian was characterized by the lowest HI and the highest TKW, together with a relatively high number of spikes $\mathrm{m}^{-2}$ but a relatively low number of kernels spike ${ }^{-1}$, while Pelayo exhibited a relatively high HI, spike $\mathrm{m}^{-2}$ and TKW and intermediate numbers of kernels spike ${ }^{-1}$. GY and all the agronomic parameters studied were significantly affected by the agronomic conditions (Table 2 and Table S2). The environment by genotype interaction was not significant for GY, BM, spikes $\mathrm{m}^{-2}$ or kernels $\mathrm{m}^{-2}$, while significant interactions were 
Table 2

Mean values for grain yield (GY), agronomic components, plant height, carbon isotope composition and $\mathrm{N}$ status parameters measured in the six selected genotypes in two crop seasons (2014-2015) Each value is the mean of the nine environments (combining specific site, year and growing conditions). Grain yield (GY), thousand kernel weight (TKW), number of kernels per spike (kernels spike ${ }^{-1}$ ), number of spikes per square meter (spikes $\mathrm{m}^{-2}$ ), number of kernels per square meter (kernels $\mathrm{m}$ ${ }^{2}$ ), kernel weight per spike (KWPS), biomass at harvest (BM), harvest index (HI), days to heading (DTH), plant height (PH), the normalized difference vegetation index (NDVI), green area (GA), greener area (GGA) and chlorophyll content (SPAD).

\begin{tabular}{|c|c|c|c|c|c|c|c|c|c|c|c|c|c|c|c|}
\hline & $\begin{array}{l}\text { Year of } \\
\text { release }\end{array}$ & $\begin{array}{l}\text { GY (Mg } \\
\left.\text { ha }^{-1}\right)\end{array}$ & TKW (g) & $\begin{array}{l}\text { Kernels } \\
\text { Spike }^{-1}\end{array}$ & spikes $\mathrm{m}^{-2}$ & kernels $\mathrm{m}^{-2}$ & KWPS (g) & $\begin{array}{l}\mathrm{BM}(\mathrm{Mg} \\
\left.\mathrm{ha}^{-1}\right)\end{array}$ & HI & DTH & $\mathrm{PH}(\mathrm{cm})$ & NDVI & GA & GGA & SPAD \\
\hline Pelayo & 2002 & $5.96^{\mathrm{a}}$ & $46.08^{c}$ & $34.05^{c}$ & $390.26^{\mathrm{ab}}$ & $13959^{\mathrm{a}}$ & $1.57^{\mathrm{c}}$ & $16.57^{\mathrm{a}}$ & $38.46^{\mathrm{b}}$ & $145.7^{\mathrm{a}}$ & $85.37^{\mathrm{d}}$ & $0.685^{\mathrm{a}}$ & $0.737^{\mathrm{b}}$ & $0.550^{\mathrm{b}}$ & $56.7^{\mathrm{a}}$ \\
\hline Sula & 1994 & $5.83^{\mathrm{a}}$ & $41.60^{\mathrm{d}}$ & $38.22^{\mathrm{b}}$ & $370.00^{\mathrm{bc}}$ & $14277^{\mathrm{a}}$ & $1.61^{\mathrm{bc}}$ & $15.87^{\mathrm{a}}$ & $38.79^{b}$ & $145.4^{\mathrm{a}}$ & $84.66^{\mathrm{cd}}$ & $0.679^{\mathrm{a}}$ & $0.807^{\mathrm{a}}$ & $0.576^{\mathrm{b}}$ & $56.7^{\mathrm{a}}$ \\
\hline Iride & 1998 & $5.80^{\mathrm{a}}$ & $42.20^{\mathrm{d}}$ & $41.37^{\mathrm{a}}$ & $333.45^{\mathrm{d}}$ & $14,498^{\mathrm{a}}$ & $1.76^{\mathrm{a}}$ & $14.98^{\mathrm{a}}$ & $41.93^{\mathrm{a}}$ & $145.9^{\mathrm{a}}$ & $85.21^{\mathrm{cd}}$ & $0.682^{\mathrm{a}}$ & $0.823^{\mathrm{a}}$ & $0.619^{\mathrm{ab}}$ & $57.4^{\mathrm{a}}$ \\
\hline Kiko Nick & 2009 & $5.70^{\mathrm{ab}}$ & $48.56^{\mathrm{ab}}$ & $29.35^{\mathrm{d}}$ & $404.32^{\mathrm{a}}$ & $12438^{\mathrm{b}}$ & $1.43^{\mathrm{d}}$ & $15.87^{\mathrm{a}}$ & $38.77^{\mathrm{b}}$ & $145.2^{\mathrm{a}}$ & $86.74^{c}$ & $0.693^{\mathrm{a}}$ & $0.796^{\mathrm{ab}}$ & $0.617^{\mathrm{ab}}$ & $57.2^{\mathrm{a}}$ \\
\hline D.Ricardo & 2008 & $5.49^{\mathrm{b}}$ & $47.45^{\mathrm{bc}}$ & $35.59^{c}$ & $346.62^{\mathrm{bc}}$ & $12532^{\mathrm{b}}$ & $1.69^{\mathrm{db}}$ & $15.84^{\mathrm{a}}$ & $37.19^{b}$ & $147.1^{\mathrm{a}}$ & $91.69^{\mathrm{b}}$ & $0.675^{\mathrm{a}}$ & $0.820^{\mathrm{a}}$ & $0.620^{\mathrm{ab}}$ & $54.9^{\mathrm{b}}$ \\
\hline D.Sebastian & 2004 & $4.69^{c}$ & $49.95^{\mathrm{a}}$ & $25.11^{\mathrm{e}}$ & $396.76^{\mathrm{ab}}$ & $10,392^{c}$ & $1.25^{\mathrm{e}}$ & $16.30^{\mathrm{a}}$ & $32.51^{c}$ & $147.5^{\mathrm{a}}$ & $96.81^{\mathrm{a}}$ & $0.691^{\mathrm{a}}$ & $0.868^{\mathrm{a}}$ & $0.661^{\mathrm{a}}$ & $55.7^{\mathrm{ab}}$ \\
\hline G & & 0.000 & 0.000 & 0.000 & 0.000 & 0.000 & 0.000 & 0.248 & 0.000 & 0.432 & 0.000 & 0.530 & 0.000 & 0.000 & 0.002 \\
\hline Env & & 0.000 & 0.000 & 0.000 & 0.000 & 0.000 & 0.000 & 0.000 & 0.000 & 0.000 & 0.000 & 0.000 & 0.000 & 0.000 & 0.000 \\
\hline$G \times E$ & & 0.130 & 0.019 & 0.001 & 0.115 & 0.263 & 0.011 & 0.140 & 0.000 & 0.231 & 0.000 & 0.913 & 0.393 & 0.682 & 0.383 \\
\hline $\mathrm{h}_{(20 \text { genotypes) }}^{2}$ & & 0.74 & 0.96 & 0.95 & 0.79 & 0.91 & 0.89 & 0.67 & 0.85 & 0.94 & 0.94 & 0.82 & 0.63 & 0.75 & 0.88 \\
\hline $\mathrm{h}_{(6,2 \text { genotypes })}^{2}$ & & 0.95 & 0.95 & 0.97 & 0.86 & 0.97 & 0.96 & - & 0.96 & 0.96 & 0.96 & 0.60 & 0.79 & 085 & 0.65 \\
\hline
\end{tabular}
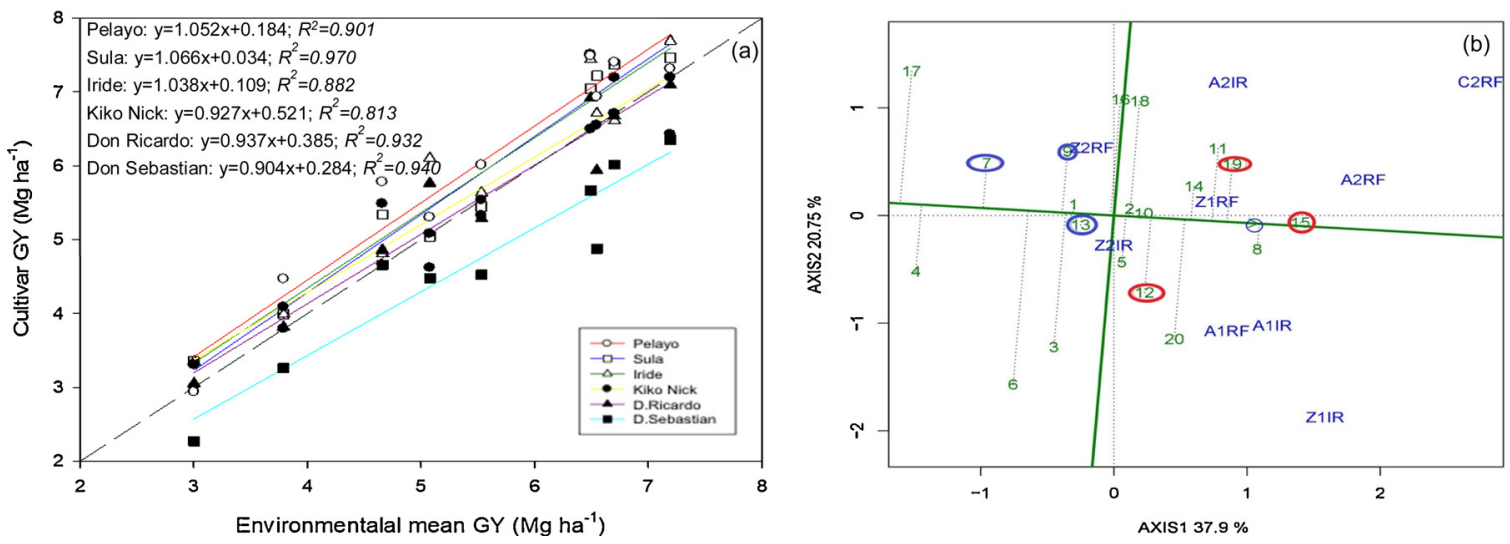

Fig. 1. (a) Regression lines showing the relationship between the individual mean grain yields (GY) of six cultivars of durum wheat in different environments and the mean yield of each environment. The environmental mean GY is the mean of a set of 20 semi-dwarf durum wheat varieties grown during the same trials. The broken line represents the 1:1 slope. All genotypes followed a similar pattern, with a regression coefficient around 1. (b) Average environment coordination (AEC) views of the GGE-biplot based on environment-focused scaling for the mean performance and stability of genotypes. Green numbers represent genotypes. (1) Amílcar, (2) Avispa, (3) Bólido, (4) Bolo, (5) Burgos, (6) Claudio, (7) Don Ricardo, (8) Don Pedro, (9) Don Sebastian, (10) Dorondon, (11) Gallareta, (12) Iride, (13) Kiko Nick, (14) Mexa, (15) Pelayo, (16) Ramirez, (17) Regallo, (18) Simeto, (19) Sula and (20) Vitron. Blue symbols represent environments: a combination of locations (A, Aranjuez; C, Coria; Z, Zamadueñas), years $(1,2014 ; 22,015)$ and treatments (RF, rainfed and IR, supplemental irrigation). The six selected genotypes have been designed by a red or blue circle, which refer to high productivity and low productivity genotypes, respectively. AXIS 1 and AXIS 2 refer to PC1 and PC2 (For interpretation of the references to colour in this figure legend, the reader is referred to the web version of this article).

observed for HI, TKW, kernels spike ${ }^{-1}$ and KWPS. In the case of GY, Fig. 1a shows graphically a non-crossover pattern across growing conditions for the six varieties with the ranking of genotypes remaining constant across environments. In addition, the AEC ordinate separates genotypes with below-average means from those with above-average means (Fig. 1 b). The genotypes with above-average means were Pelayo, Iride, and Sula and those with below average means were Don Sebastian, Don Ricardo, and Kiko Nick. Both Pelayo and Don Sebastian seemed stable even though they had different yields. Conversely, Iride, Sula, Kiko Nick, and Don Ricardo were more variable.

\subsection{Plant height, vegetation indices and morphological traits}

Plant height $(\mathrm{PH})$ and all vegetation indices measured in early grain filling exhibited a significant year effect and genotypic variation, except for NDVI (Table S1). When combining the two-year data, significant differences between genotypes existed for $\mathrm{pH}$ and all vegetation indices except NDVI (Table 2). Across varieties $\mathrm{pH}$ ranged between $96.8 \mathrm{~cm}$ (Don Sebastian) and $84.7 \mathrm{~cm}$ (Sula), with Pelayo being among the shortest of the genotypes $(85.4 \mathrm{~cm})$. The GA and GGA indices ranged from 0.868 and 0.661 (Don Sebastian) to 0.737 and 0.550 (Pelayo), respectively. No differences in leaf chlorophyll content were recorded between the two extreme genotypes (Pelayo and Don Sebastian). $\mathrm{pH}$ and all vegetation indices were significantly affected by the environment (Table 2), and the environment by genotype interaction was significant for $\mathrm{pH}$ but not for any of the vegetation indices. Considering only the second year (Table S3), the same pattern of differences was recorded between the canopy vegetation indices measured at early grain filling for the extreme genotypes, but they only reached significance for SPAD $(P<0.05)$ and marginally $(P=0.09)$ for GA. However, for the second year, significant genotype variation existed for GA $(P<0.05)$ measured at booting and mid grain filling, while the significance was marginal at early $(P=0.09)$ and late $(P=0.07)$ grain filling (Fig. 2). Genotype variation also existed for NDVI $(\mathrm{P}<0.01)$ at mid grain filling, and for Leaf $\mathrm{Chl}$ at early grain filling. Throughout the productive period Don Sebastian tended to have the highest values for GA and NDVI and Pelayo the lowest (Fig. 2), and the same occurred for GGA (data not shown).

Significant genotype and environment effects were observed for leaf length $(\mathrm{P}<0.001)$, leaf width $(\mathrm{P}<0.01)$ and spike length $(P<0.05)$, which were measured in the second year (Table S3). The environment by genotype interaction was not significant for any of the traits except leaf length. Leaf length ranged between $18.2 \mathrm{~cm}$ (Iride) and $21.96 \mathrm{~cm}$ (Don Ricardo). Spike length ranged between $6.48 \mathrm{~cm}$ 

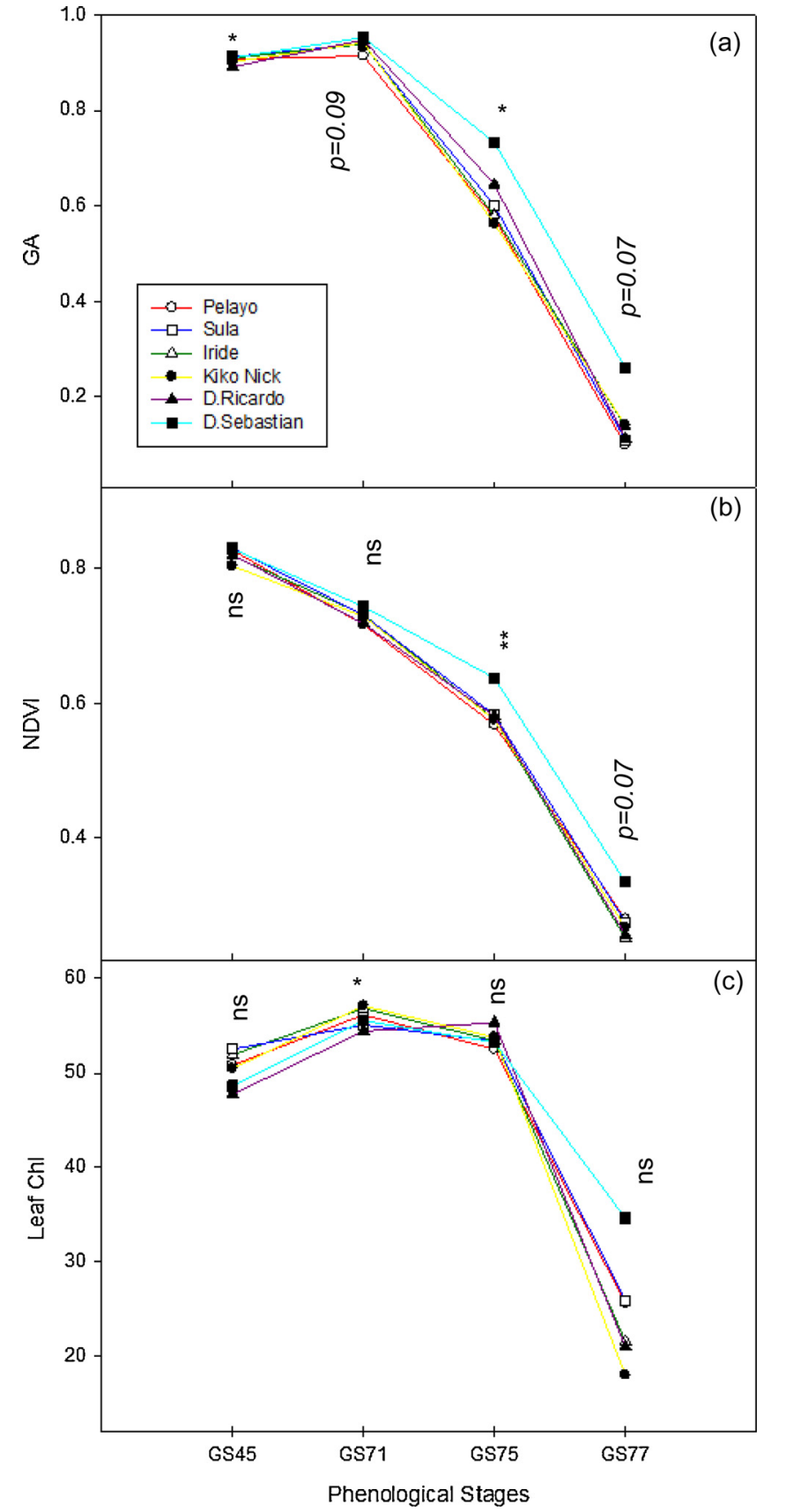

Fig. 2. Mean values of GA(a), the NDVI (b) and leaf chlorophyll content (c) at different phenological stages. Each point is the mean of five environments with three replicates in each environment. Each line represents a genotype. Probabilities (ns, not significant; *, P < 0.05; **, P $<0.01$ ) are shown.

(Kiko Nick) and 7.19 (Iride).

\subsection{Water and $N$ status parameters}

Water and $\mathrm{N}$ status parameters exhibited a significant year effect and genotypic variation for all traits except for canopy temperature depression (CTD) (Table S4). Considering the nine environments, both the growing condition and genotype had a significant effect on the kernel carbon isotope composition $\left(\delta^{13} \mathrm{C}_{\text {Kernel }}\right)$, CTD, kernel $\mathrm{N}$ content and KNSP (Table 3 ) and no genotypic effect on nitrogen isotope composition $\left(\delta^{15} \mathrm{~N}_{\text {Kernel }}\right)$. Don Sebastian exhibited the highest $\delta^{13} \mathrm{C}_{\text {Kernel }}$ $(-25.25 \%)$ and the lowest CTD $\left(4.28^{\circ} \mathrm{C}\right)$, while Pelayo had the lowest $\delta^{13} \mathrm{C}_{\text {Kernel }}(-25.74 \%)$, and a high CTD $\left(5.15^{\circ} \mathrm{C}\right)$. In addition, Don
Sebastian exhibited the highest $\mathrm{N}_{\text {kernel }}(2.61 \%)$ but the lowest KNPS (31.7 mg), while Pelayo had the lowest $\mathrm{N}_{\text {kernel }}(2.35 \%$ ) and the highest KNPS (36.2 mg). A genotype by environment interaction was identified for $\delta^{15} \mathrm{~N}_{\text {Kernel, }}$ and also marginally for CTD and $\mathrm{N}_{\text {kernel }}$, but not for $\delta^{13} \mathrm{C}_{\text {kernel. }}$. Even so, a trend for a crossover in $\delta^{13} \mathrm{C}_{\text {Kernel }}$ was observed in the less productive environments (Fig. 3).

\subsection{Carbon isotope composition in different tissues}

Significant genotype variation was exhibited in $\delta^{13} \mathrm{C}$ for all tissues except $\delta^{13} \mathrm{C}_{\text {glume.DM }}$ and $\delta^{13} \mathrm{C}_{\text {peduncle.DM }}$ and $\delta^{13} \mathrm{C}_{\text {awns.WSF }}$ and $\delta^{13} \mathrm{C}_{\text {peduncle.wsF }}$ (Table S5). The $\delta^{13} \mathrm{C}$ of different organs was significantly affected by environmental conditions, except for $\delta^{13} \mathrm{C}_{\text {peduncle.DM, }}$, and only marginally for $\delta^{13} \mathrm{C}_{\text {lemma.wsF. The environment }}$ by genotype interaction was highly significant for all tissues except for $\delta^{13} \mathrm{C}_{\text {glume.DM, }} \delta^{13} \mathrm{C}_{\text {peduncle.DM, and }} \delta^{13} \mathrm{C}_{\text {awns.wsF, where it was not sig- }}$ nificant, and for $\delta^{13} \mathrm{C}_{\text {pedunclewsF, }} \delta^{13} \mathrm{C}_{\text {leaf.WSF }}$ and $\delta^{13} \mathrm{C}_{\text {leaf.wSF}}$, where it was just marginally significant. While no differences in $\delta^{13} \mathrm{C}$ existed between DM and WSF for awns, leaves and peduncles, the values were higher (less negative) in WSF compared to the DM of the other three organs of the spike. Significant differences in $\delta^{13} \mathrm{C}$ values were observed across plant organs, with both the DM and WSF of the peduncle and flag leaf blades having the highest and the lowest $\delta^{13} \mathrm{C}$ values, respectively (Fig. 4). The values of $\delta^{13} \mathrm{C}_{\text {Kernel }}$ were significantly different to the $\delta^{13} \mathrm{C}$ of the other plant parts with the exception of $\delta^{13} \mathrm{C}_{\text {lemma.DM }}$ and

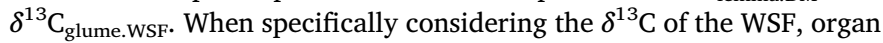
values of the peduncles, glumes, lemmas and paleas were higher and those of the awns and the leaves were lower than the $\delta^{13} \mathrm{C}_{\text {Kernel. With }}$ regard to the $\mathrm{DM}$, the $\delta^{13} \mathrm{C}$ organ values of the paleas and peduncles were higher while those of glumes, lemmas, awns and leaves were lower than the $\delta^{13} \mathrm{C}_{\text {Kernel }}$ (Fig. 4).

\subsection{Relationship between $\delta^{13} C, G Y$ and yield components across growing conditions}

The correlations of $\delta^{13} \mathrm{C}$ with GY and the agronomic yield components were examined (Fig. 5). The relationship of the $\delta^{13} \mathrm{C}$ of kernels, flag leaves, peduncles and different parts of the ears (glumes, lemma, palea and awns) against GY and yield components were plotted using the whole set of individual measurements for each of the five growing conditions of this study (the second growing season). The $\delta^{13} \mathrm{C}_{\text {kernels }}$ correlated negatively with GY in four of the five growing conditions. The $\delta^{13} \mathrm{C}$ of the different plant parts other than kernels correlate in few cases with GY;indeed, the $\delta^{13} \mathrm{C}$ of some ear parts when measured in WSF for a couple of growing conditions and the $\delta^{13} \mathrm{C}$ of the flag leaf DM in one growing condition. The relationships between $\delta^{13} \mathrm{C}_{\text {kernels }}$ and TKW were positive but only achieved statistical significance for two growing conditions. No correlation was found between $\delta^{13} \mathrm{C}_{\text {kernels }}$ and the other agronomic components. $\delta^{13} \mathrm{C}_{\text {leaf.DM }}$ correlated negatively with TKW, achieving significance in three of the five growing conditions and also correlated positively with kernels spike ${ }^{-1}$, achieving significance in four of the five growing conditions. By contrast, when the $\delta^{13} \mathrm{C}$ of the WSF was considered, the values of some ear parts correlated significantly with the two yield components determined during the last part of the crop cycle: against kernels spike ${ }^{-1}$ in three of the five environments and against TKW in four of the five environments.

\subsection{Relationships of leaf length with $\delta^{13} C$ and $G Y$}

The relationships between GY and leaf length were negative but only achieved statistical significance under rainfed conditions in Zam and Aran (Fig. 6) using the six genotypes and three replicates of this study (18 values) as well as the whole set of 20 genotypes reported in Chairi et al. [7] (60 values). The leaf length correlated positively with $\delta^{13} \mathrm{C}_{\text {kernels }}$ within the rainfed conditions of Zam and Aran. 
Table 3

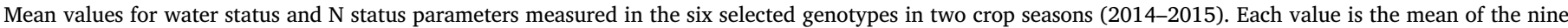

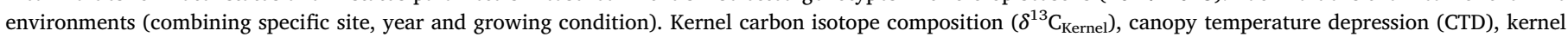
nitrogen isotope composition $\left(\delta^{15} \mathrm{~N}_{\text {Kernel }}\right)$, kernel nitrogen content $\left(\mathrm{N}_{\text {Kernel }}\right)$ and total kernel nitrogen per spike (KNPS).

\begin{tabular}{|c|c|c|c|c|c|}
\hline & $\delta^{13} \mathrm{C}_{\text {kernel }}(\% 0)$ & CTD $\left({ }^{\circ} \mathrm{C}\right)$ & $\delta^{15} \mathrm{~N}_{\text {Kernel }}(\% 0)$ & $\mathrm{N}_{\text {Kernel }}(\%)$ & KNPS (mg) \\
\hline Pelayo & $-25.74^{\mathrm{b}}$ & $5.15^{\mathrm{ab}}$ & $4.19^{\mathrm{a}}$ & $2.35^{\mathrm{bc}}$ & $36.2^{\mathrm{b}}$ \\
\hline Sula & $-25.70^{\mathrm{b}}$ & $5.35^{\mathrm{ab}}$ & $4.31^{\mathrm{a}}$ & $2.32^{\mathrm{cd}}$ & $35.5^{\mathrm{bc}}$ \\
\hline Iride & $-25.65^{\mathrm{b}}$ & $4.73^{\mathrm{ab}}$ & $4.27^{\mathrm{a}}$ & $2.20^{\mathrm{d}}$ & $38.1^{\mathrm{ab}}$ \\
\hline Kiko Nick & $-25.56^{\mathrm{b}}$ & $4.45^{\mathrm{b}}$ & $4.50^{\mathrm{a}}$ & $2.60^{\mathrm{a}}$ & $37.1^{\mathrm{ab}}$ \\
\hline D.Ricardo & $-25.59^{b}$ & $5.75^{\mathrm{a}}$ & $4.53^{\mathrm{a}}$ & $2.48^{\mathrm{ab}}$ & $41.0^{\mathrm{a}}$ \\
\hline D.Sebastian & $-25.25^{\mathrm{a}}$ & $4.28^{\mathrm{b}}$ & $4.57^{\mathrm{a}}$ & $2.61^{\mathrm{a}}$ & $31.7^{c}$ \\
\hline G & 0.003 & 0.037 & 0.145 & 0.000 & 0.000 \\
\hline Env & 0.000 & 0.000 & 0.000 & 0.000 & 0.000 \\
\hline$G \times E$ & 0.250 & 0.046 & 0.018 & 0.050 & 0.231 \\
\hline $\mathrm{h}_{(20 \text { genotypes })}^{2}$ & 0.38 & - & - & 0.69 & 0.79 \\
\hline $\mathrm{h}_{(6 \text { genotypes })}^{2}$ & 0.48 & - & - & 0.86 & 0.86 \\
\hline
\end{tabular}

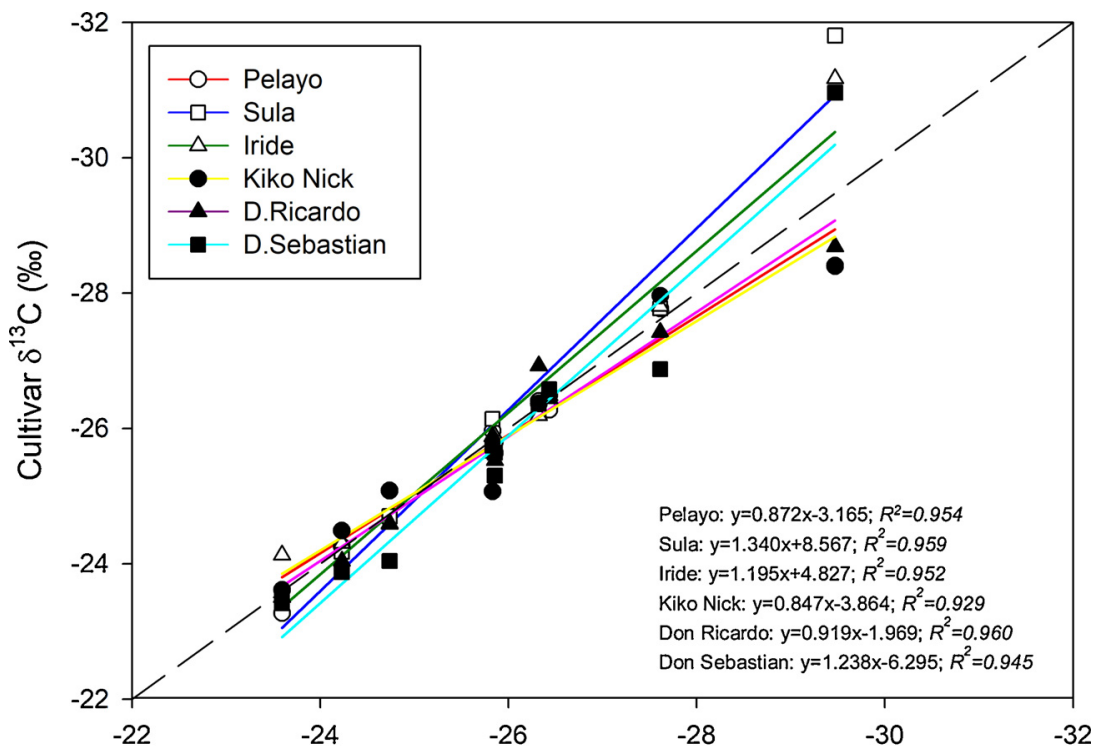

Fig. 3. Regression lines showing the relationship between the individual mean carbon isotope composition $\left(\delta^{13} \mathrm{C}\right)$ of kernels of six of durum wheat genotypes at different locations and the mean $\delta^{13} \mathrm{C}$ of each environment. The environmental mean is the mean of a set of 20 durum wheat semi-dwarf varieties grown during the same trials. The broken line represents the $1: 1$ slope.

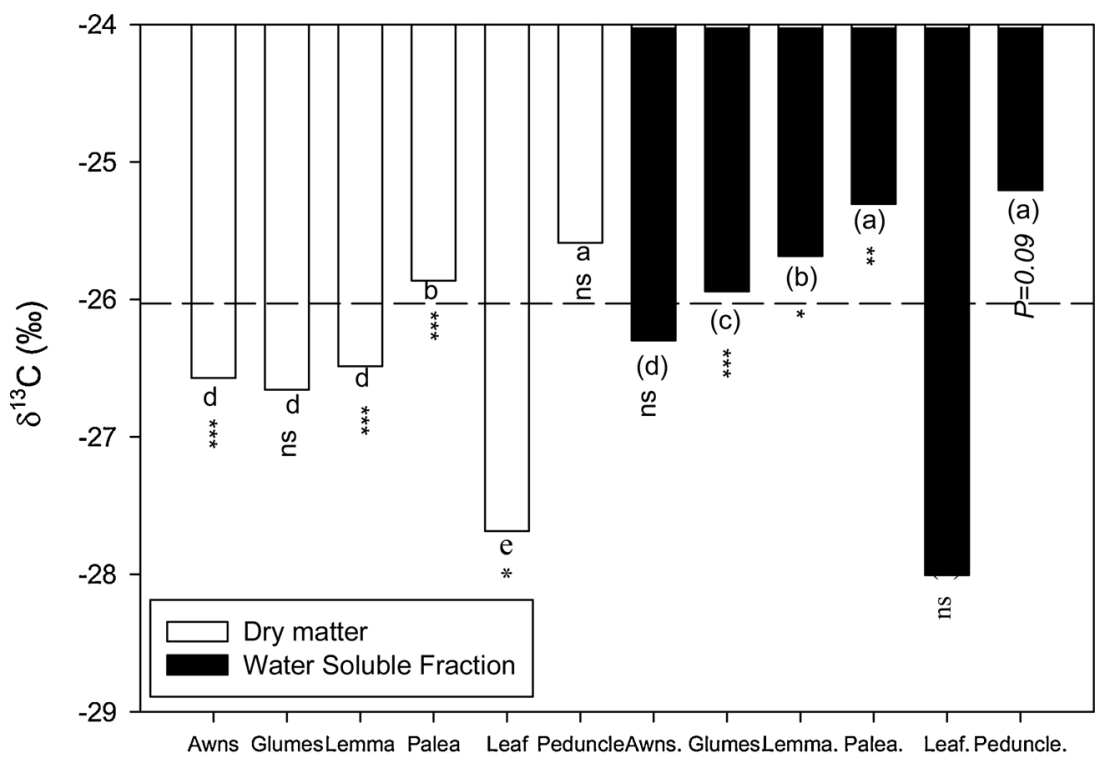

Fig. 4. Carbon isotope composition $\left(\delta^{13} \mathrm{C}\right)$ of the different organs at early-grain filling in dry matter and the water-soluble fraction (filled and open bars) compared to the $\delta^{13} \mathrm{C}$ of the kernels (dashed horizontal line). Each bar represents the mean $\delta^{13} \mathrm{C}$ of the six genotypes in all environments. Mean values with different superscript letters are significantly different between different organs according to Duncan's test $(P<0.05)$. Probabilities of the genotype by environment interaction (ns, not significant; *, P $<0.05$; **, $\mathrm{P}<0.01$, ***, $\mathrm{P}<0.001$ ) are shown. 

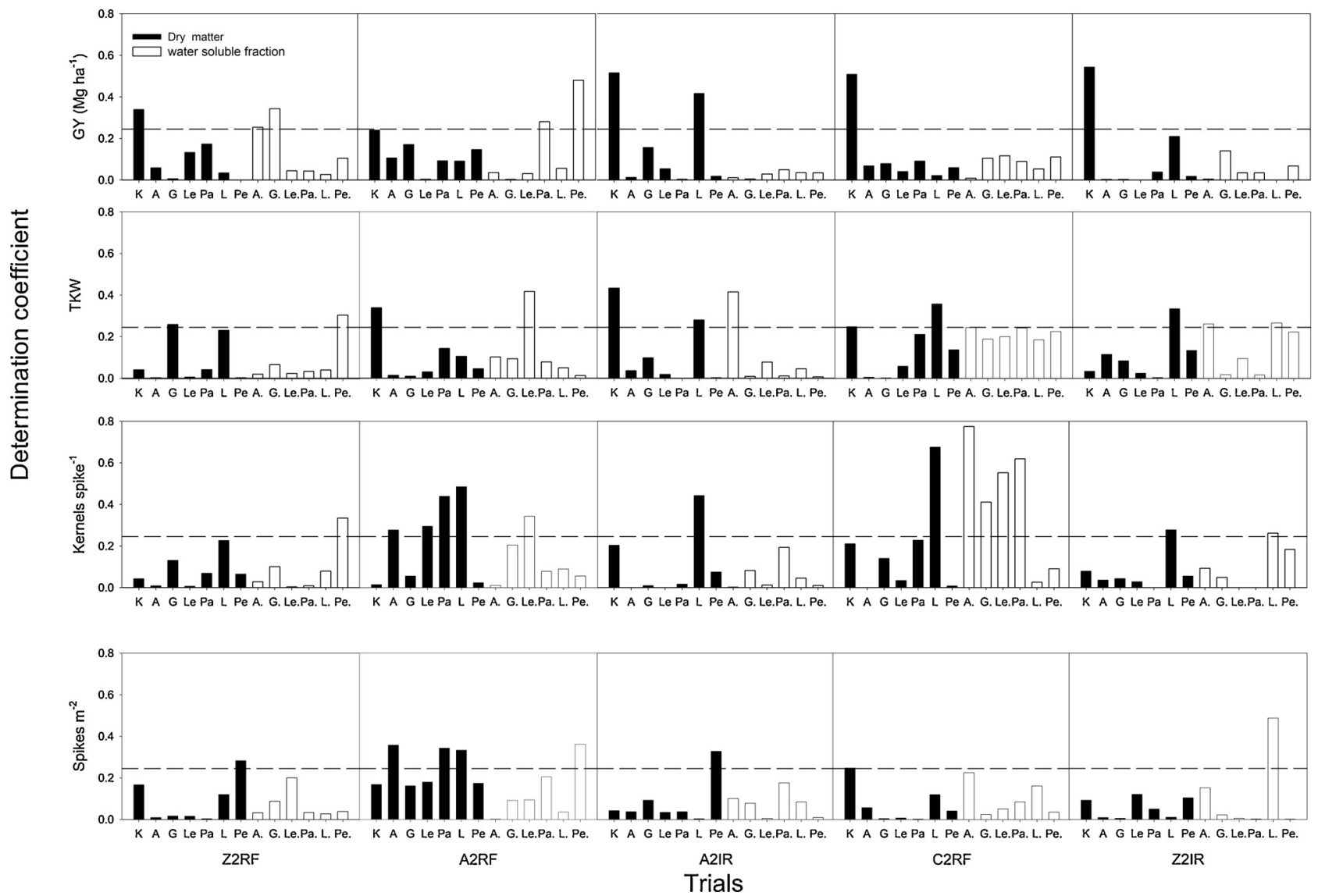

Fig. 5. Relationship between grain yield, TKW, kernels spike ${ }^{-1}$, spikes $\mathrm{m}^{-2}$, and carbon isotope composition of mature kernels (K), flag leaves (L), different parts of the ear (awns, A; glume, G; lemma, Le; palea; P) and the peduncle (Pe) in dry matter and the water-soluble fraction in each environment (see Trial codes in Table 1). The horizontal broken line refers to the significance level $(\mathrm{P}<0.05)$ of the relationship of each isotopic signature against the grain yield.

\subsection{Broad sense heritability}

The broad sense heritability $\left(\mathrm{h}^{2}\right)$ of the different parameters studied in this work were in general high (Tables 2,3) using the six selected genotypes, as well as the whole set of 20 genotypes reported in the previous study [7]. Even so, $\mathrm{h}^{2}$ values were in general slightly higher when calculated for the subset of six genotypes exhibiting contrasting grain yield than for the complete panel of 20 genotypes. Moreover, yield components had higher $\mathrm{h}^{2}$ (TKW, 0.96; kernels spike ${ }^{-1}, 0.95$; spikes $\mathrm{m}^{-2}, 0.79$; kernels $\mathrm{m}^{-2}, 0.91$; HI, 0.85; KWPS, 0.89) than yield (GY, 0.74) and biomass (BM, 0.67) when using the whole set of 20 durum wheat genotypes (Table 2, S2), while differences were not so evident when $\mathrm{h}^{2}$ was calculated only using the six genotypes. The vegetation indices had a higher $\mathrm{h}^{2}$ (NDVI, 0.82; GGA, 0.75; SPAD, 0.88) than grain yield except for GA (GA, 0.63) and $\delta^{13} \mathrm{C}_{\text {kernel }}\left(\delta^{13} \mathrm{C}_{\text {kernel, }}\right.$ 0.38 ) when $\mathrm{h}^{2}$ was calculated for the whole set of 20 genotypes, while differences were not so evident when it was calculated for the six contrasting genotypes alone. $\mathrm{N}_{\text {Kernel }}$ and KNPS had comparable $\mathrm{h}^{2}$ values $\left(\mathrm{N}_{\text {Kernel }}, 0.69\right.$ and KNPS, 0.79) than GY (Table 3). Considering only the second year, the $\mathrm{h}^{2}$ of the DTH (0.97) and the morphological parameters (LL, 0.87; SL, 0.77, PH, 0.89) also had higher $\mathrm{h}^{2}$ values than GY (0.63), while LW (LW, 0.55) was the exception (Table S2, S3). For the $\delta^{13} \mathrm{C}$ of the different plant tissues measured for the six selected genotypes in the second growing season alone, the $\mathrm{h}^{2}$ values observed were in general moderate to high but lower than the other parameters (Table S5). High values of $\mathrm{h}^{2}$ were observed for $\delta^{13} \mathrm{C}_{\text {kernel }}(0.87)$, $\delta^{13} \mathrm{C}_{\text {leaf.DM }}$ (0.97), $\delta^{13} \mathrm{C}_{\text {awns.WSF }}(0.62)$ and $\delta^{13} \mathrm{C}_{\text {peduncle.wSF }}(0.82)$. Moderate values were observed for $\delta^{13} \mathrm{C}_{\text {lemme.DM }}(0.47) ; \delta^{13} \mathrm{C}_{\text {palea.DM }}$ (0.42) and low values for $\delta^{13} C_{\text {awns.DM }}(0.32)$ and $\delta^{13} C_{\text {glume.wSF }}(0.31)$.

\subsection{Stepwise analysis and PCA}

The environments were separated into two subsets, high yielding (HY, GY > $5.8 \mathrm{Mg} \mathrm{ha}^{-1}$, comprising A1RF, A1IR, Z1IR, C2RF and Z2IR growing conditions) and low yielding ( $\mathrm{LY}, \mathrm{GY}<5.8 \mathrm{Mg} \mathrm{ha}^{-1}$, including Z1RF, A2RF, A2IR and Z2RF growing conditions) and the stepwise regression analysis between GY, as the dependent variable, and the agronomic yield components (spikes $\mathrm{m}^{-2}$, kernels spike ${ }^{-1}$ and TKW) as independent variables were calculated. Under high yielding conditions kernels spike ${ }^{-1}$ was the first variable chosen by the model and under low yielding conditions the spike $\mathrm{m}^{-2}$ was the first variable in the model (Table 4). Stepwise analysis was also performed within each agronomic condition in the second year. In four of the five environments, kernels spike ${ }^{-1}$ was the first component chosen followed by spikes $\mathrm{m}^{-2}$ (Table 4). Also, a stepwise analysis was performed under the two growing conditions, the HY and LY environments, using GY and yield components as dependent variables, and water status parameters $\left(\delta^{13} \mathrm{C}_{\text {kernels }}\right.$ and CTD) and remote sensing indices as independent variables (NDVI, SPAD, GA and GGA). Under both the HY and LY environments (Table 5) $\delta^{13} \mathrm{C}_{\text {kernels }}$ was the first variable chosen followed by GGA. For TKW, $\delta^{13} \mathrm{C}_{\text {kernels }}$ was the first variable chosen in the HY environment and SPAD in the LY environment. For kernels spike ${ }^{-1}$, $\mathrm{N}_{\text {kernel }}$ was the first variable chosen in both the HY and LY environments. However, for spikes $\mathrm{m}^{-2}$, NDVI was the first variable chosen in both the HY and LY environments, followed by CTD in the LY environment and $\delta^{13} \mathrm{C}_{\text {kernels }}$ in HY environment. Together with the stepwise analysis a PCA was performed for each environment (Fig. 7) using first the GY and agronomic GY components and second the GY and physiological traits. In the four cases, the two first principal components (PC) explained $>60 \%$ of the observed variability under the HY 

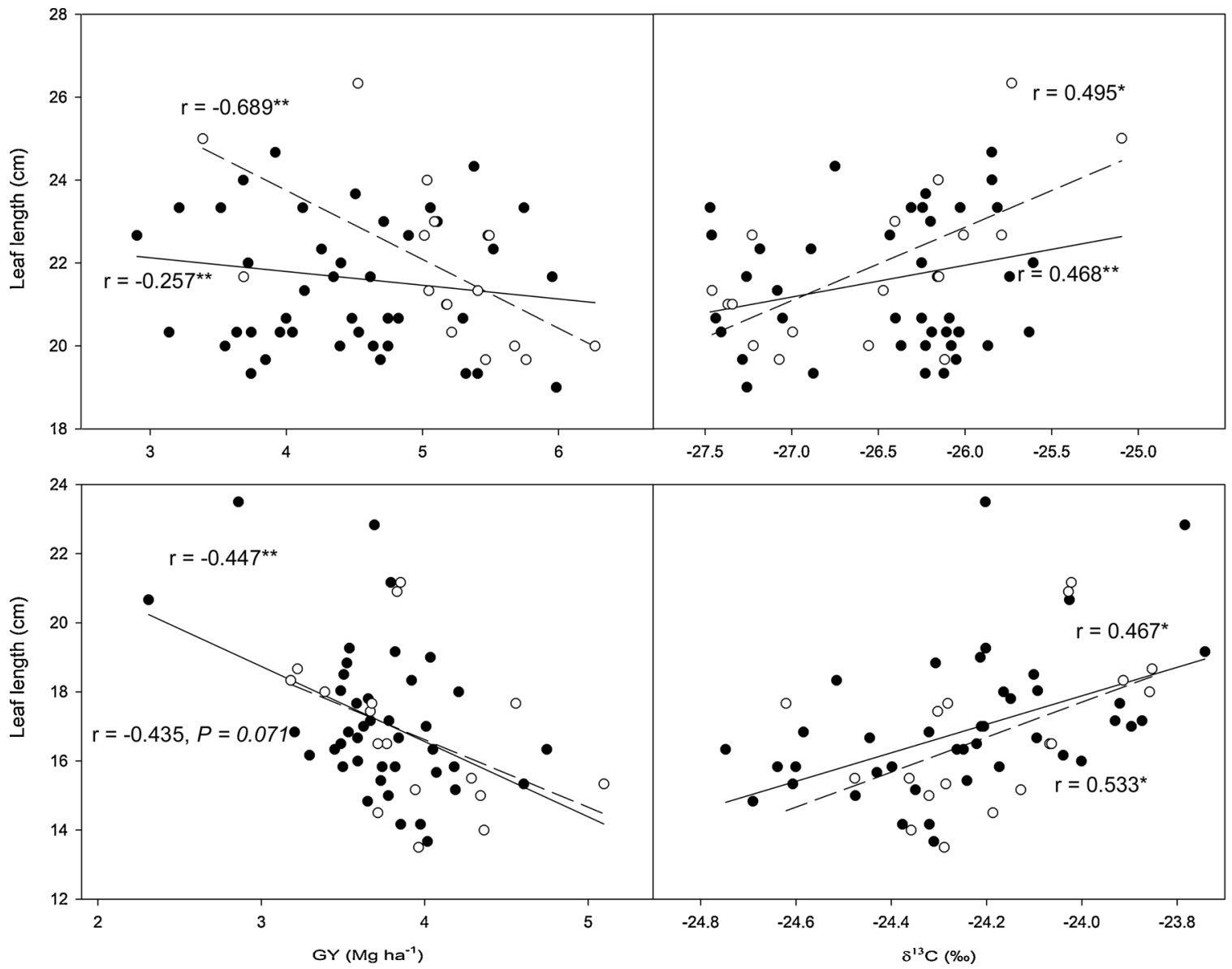

Fig. 6. Relationships between leaf length and grain yield (GY) and carbon isotope composition $\left(\delta^{13} \mathrm{C}_{\text {kernel }}\right)$ measured in twenty durum wheat (solid lines and filled circles) and six durum wheat genotypes (broken lines and open circles) grown under rainfed conditions in two locations: Aranjuez (a,b) and Zamadueñas (c,d). Probabilities $(*, \mathrm{P}<0.05 ; * *, \mathrm{P}<0.01)$ are shown.

Table 4

Stepwise regression analysis between grain yield (GY) as dependent variables and agronomic yield components (TKW, spikes $\mathrm{m}^{-2}$, and kernels spike ${ }^{-1}$ ) as independent variables of six genotypes of durum wheat grown under different environments. Top: under the two growing seasons (2014 and 2015) separated into high yielding (HY) and low yielding (LY) environments. LY included the Z1RF, A2RF, A2IR and Z2RF trials, while HY included the remaining A1RF, A1IR, Z1IR, C2RF and Z2IR trials. Bottom: under each environment in the second season (2015).

\begin{tabular}{llll}
\hline \multirow{2}{*}{ Environment } & Variable/s chosen & Adjusted R & $P$ \\
\hline \multirow{2}{*}{ LY } & Spikes m-2 & 0.241 & 0.000 \\
& Spikes m-2, Kernels Spike-1 & 0.887 & 0.000 \\
HY & Spikes m-2, Kernels Spike-1,TKW & 0.982 & 0.000 \\
& Kernels Spike-1 & 0.131 & 0.004 \\
& Kernels Spike-1, Spikes m-2 & 0.567 & 0.000 \\
Z2RF & Kernels Spikes-1, Spikes m-2,TKW & 0.675 & 0.000 \\
& Kernels Spike-1 & 0.226 & 0.027 \\
A2RF & Kernels Spikes-1, Spikes m-2 & 0.549 & 0.001 \\
& Spikes m-2 & 0.652 & 0.000 \\
& Spikes m-2, Kernels Spike-1 & 0.868 & 0.000 \\
A2IR & Spikes m-2, Kernels Spike-1,TKW & 0.954 & 0.000 \\
& Kernels Spike-1 & 0.328 & 0.024 \\
& Kernels Spike-1, Spikes m-2 & 0.840 & 0.000 \\
C2RF & Kernels Spikes-1, Spikes m-2,TKW & 0.954 & 0.000 \\
\multirow{2}{*}{ Z2IR } & Kernels Spike-1 & 0.288 & 0.013 \\
& Kernels Spike-1, Spikes m-2 & 0.699 & 0.000 \\
& Kernels Spike & 0.003 \\
\hline
\end{tabular}

and LY environments (Fig. 7). Kernels spike ${ }^{-1}$ and spikes $\mathrm{m}^{-2}$ were the two agronomic components most closely related to GY under the HY and LY environments (Fig. 7a, b). TKW was negatively related to TKW under low yielding conditions. Among the physiological traits, $\delta^{13} \mathrm{C}$ and nitrogen kernel presented a negative association with GY in both environments while the vegetation indices were positively associated (Fig. 7). The CTD was closely associated with GY in the LY environment and to a lesser extent in the HY environment (Fig. 7c). The SPAD index was closely associated with GY under the HY environment (Fig. 7d). The two categories of genotypes (Pelayo, Sula and Iride on the one hand and Kiko Nick, Don Ricardo and Don Sebastian on the other) were clearly separated.

\section{Discussion}

The six semi-dwarf varieties used in this study were released over a period of just 15 years. In spite of the significant genotypic differences among grain yields, these varieties did not follow a pattern of increasing productivity over time. This fact reinforces the conclusion of a lack of a clear strategy in breeding durum wheat for Spanish conditions, at least in terms of grain yield as a target [7]. Moreover, the lack of a genotype by environment interaction for grain yield indicates that the varieties tested here do not seem to be suited to any particular environment, and hence this does not support the view that breeding has led to genetic advances for the warmer conditions of South Spain [7]. In the high yielding conditions of the UK [47] and NW Mexico [48], genetic advance in wheat grain yield has been reported. Moreover, and contrasting with our results, the study of Pennachi et al. [47] supports 
Table 5

Stepwise analysis with grain yield (GY), thousand kernel weight (TKW), kernels per spike (kernels spike-1) and spikes per square meter (spikes m-2) as dependent variables for six durum wheat genotypes under two growing seasons (2014 and 2015) separated into high yielding (HY) and low yielding (LY) environments. The independent variables were chlorophyll content at grain filling (SPAD), carbon isotope composition $\left(\delta^{13} \mathrm{C}_{\mathrm{kernel}}\right)$, vegetation indices at grain filling (GA, GGA and NDVI), canopy temperature depression (CTD), and N content $\left(\mathrm{N}_{\text {Kernel }}\right)$.

\begin{tabular}{|c|c|c|c|c|}
\hline Environment & $\begin{array}{l}\text { Predicted } \\
\text { variable }\end{array}$ & Variable/s chosen & Adjusted $\mathrm{R}^{2}$ & Pvalue \\
\hline \multirow[t]{12}{*}{ LY } & \multirow[t]{3}{*}{ GY } & $\delta^{13} \mathrm{C}_{\text {kernel }}(-)$ & 0.676 & 0.000 \\
\hline & & $\delta^{13} C_{\text {kernel }}(-)$; GGA $(+)$ & 0.726 & 0.000 \\
\hline & & $\begin{array}{l}\delta^{13} C_{\text {kernel }}(-) ; \text { GGA }(+) \\
\operatorname{SPAD}(+)\end{array}$ & 0.749 & 0.000 \\
\hline & \multirow[t]{4}{*}{ TKW } & $\operatorname{SPAD}(+)$ & 0.056 & 0.034 \\
\hline & & $\operatorname{SPAD}(+) ; \operatorname{NDVI}(-)$ & 0.179 & 0.001 \\
\hline & & $\begin{array}{l}\operatorname{SPAD}(+) ; \operatorname{NDVI}(-) \\
\mathrm{GGA}(+)\end{array}$ & 0.292 & 0.000 \\
\hline & & $\begin{array}{l}\operatorname{SPAD}(+) ; \operatorname{NDVI}(-) \\
\operatorname{GGA}(+) ; \operatorname{CTD}(+)\end{array}$ & 0.340 & 0.000 \\
\hline & \multirow[t]{3}{*}{$\begin{array}{l}\text { Kernels } \\
\text { spike }^{-1}\end{array}$} & $\mathrm{~N}_{\text {kernel }}(-)$ & 0.007 & 0.007 \\
\hline & & $\mathrm{N}_{\text {kernel }}(-)$;NDVI (-) & 0.002 & 0.002 \\
\hline & & $\begin{array}{l}\mathrm{N}_{\text {kernel }}(-) \text {; NDVI(-); } \\
\text { GGA(+) }\end{array}$ & 0.000 & 0.000 \\
\hline & \multirow[t]{2}{*}{ Spikes $\mathrm{m}^{-2}$} & NDVI $(+)$ & 0.433 & 0.000 \\
\hline & & $\operatorname{NDVI}(+)$; CTD $(+)$ & 0.467 & 0.000 \\
\hline \multirow[t]{13}{*}{ HY } & \multirow[t]{3}{*}{ GY } & $\delta^{13} \mathrm{C}_{\text {kernel }}(-)$ & 0.136 & 0.001 \\
\hline & & $\delta^{13} \mathrm{C}_{\text {kernel }}(-)$; GGA $(+)$ & 0.217 & 0.000 \\
\hline & & $\begin{array}{l}\delta^{13} \mathrm{C}_{\text {kernel }}(-) \text {; GGA }(+) \\
\mathrm{N}_{\text {kernel }}(+)\end{array}$ & 0.267 & 0.000 \\
\hline & \multirow[t]{2}{*}{ TKW } & $\delta^{13} C_{\text {kernel }}(-)$ & 0.340 & 0.000 \\
\hline & & $\delta^{13} \mathrm{C}_{\text {kernel }}(-) ; \mathrm{GA}$ & 0.398 & 0.000 \\
\hline & \multirow[t]{3}{*}{$\begin{array}{l}\text { Kernels } \\
\text { spike }^{-1}\end{array}$} & $\mathrm{~N}_{\text {kernel }}(-)$ & 0.269 & 0.000 \\
\hline & & $\mathrm{N}_{\text {kernel }}(-)$; GA(-) & 0.527 & 0.000 \\
\hline & & $\mathrm{N}_{\text {kernel }}(-)$; GA(-); NDVI(-) & 0.577 & 0.000 \\
\hline & \multirow[t]{5}{*}{ Spikes $\mathrm{m}^{-2}$} & $\operatorname{NDVI}(+)$ & 0.453 & 0.000 \\
\hline & & $\operatorname{NDVI}(+) ; \delta^{13} C_{\text {kernel }}(-)$ & 0.514 & 0.000 \\
\hline & & $\operatorname{NDVI}(+) ; \delta^{13} C_{\text {kernel }}$ & 0.539 & 0.000 \\
\hline & & $(-) ; \mathrm{N}_{\text {kernel }}(+)$ & & \\
\hline & & $\begin{array}{l}\text { NDVI( }+) ; \delta^{13} C_{\text {kernel }} \\
(-) ; N_{\text {kernel }}(+) ; \mathrm{GA}(+)\end{array}$ & 0.570 & 0.000 \\
\hline
\end{tabular}

the contention that breeding for yield potential does not select for climate resilience and yield stability in wheat. However, a recent study [49] using a large set of cultivars released over 50 years in Germany reported that breeding for high performance not only enhanced cultivar performance under optimal production conditions but also increased performance in production systems with reduced agrochemical inputs. This study concluded that new cultivars incrementally accumulated genetic variants conferring favorable effects on key yield parameters and disease resistance. In the present work, Don Sebastian exhibited the poorest yield in all environments and consistently produced belowaverage yields, proving that it is poorly adapted to all environments. The other varieties maintained higher yields in all environments, which indicates that they have general adaptability. This included Pelayo, which exhibited a linear fit to the Finlay and Wilkinson model [50] above the other genotypes and without any crossover in the lines. Also, the average environment coordination (AEC) method [45] revealed that Pelayo had the highest mean yield as well as the highest stability.

Subsequently we dissected the agronomic, physiological and morphological characters related to the consistent differences in yield across this set of six varieties. In this study, the number of days from sowing to heading (DTH) did not differ statistically among genotypes, which excludes differences in phenology as one of the causes of differences in $\delta^{13} \mathrm{C}$ and grain yield [51,52].

Retrospective studies on wheat, combining pre- and post-green revolution cultivars, indicate that the improvement in yield has more often been associated with augmented partitioning of biomass to the grain, and associated in turn with a decrease in stature, than with enhanced overall biomass [53-55]. Thus plant height is usually negatively correlated with the HI [11]. The few studies embracing only post green revolution genotypes frequently include transitional genotypes from the 1960 s and 1970s, with relatively tall plants $[5,56]$. Otherwise no clear effect on differences in plant height or increased biomass have been reported [57], even though some studies report an increase in biomass associated with recent genetic advance in wheat cultivated under good agronomic conditions [54,58]. Indeed, in our study, the most productive genotypes (Pelayo, Sula and Iride) exhibited higher HI together with lower plant height than the less productive ones (Don Sebastian, Don Ricardo and Kiko Nick), with no differences in biomass. As reported in studies comparing pre- and post-green revolution genotypes $[6,11,54]$, a higher HI seems related to greater numbers of kernels per spike, whereas the TKW did not change. As a consequence, a higher HI indirectly translates to greater numbers of kernels $\mathrm{m}^{-2}$. Most studies agree that kernels $\mathrm{m}^{-2}$ best explains yield [59-61]. In our study, genotypes with higher GY were associated with more kernels $\mathrm{m}^{-2}$, while the contribution of TKW was minor. The increase in kernels $\mathrm{m}^{-2}$ was mostly due to an increase in kernels spike ${ }^{-1}[7,11,62]$. The stepwise and PCA analyses indicated that kernels spike ${ }^{-1}$ was better associated with $\mathrm{GY}$ in high and low yielding environments than spikes $\mathrm{m}^{-2}$, while TKW was not associated at all. Other studies have also shown that kernels spike $^{-1}$ was associated with GY under a high-yielding environment [63] and also under water stress conditions [64]. A positive relationship between the number of kernels spike- $[7,11]$ and grain yield seems to have been derived from the fact that grain yield in wheat is frequently sink limited [65], and for this reason, kernels spike ${ }^{-1}$ has been reported as a promising trait for increasing wheat grain yield $[64,65]$.

Regarding durum wheat in Spain, the above results suggest that a certain point was reached where new cultivars represented a step backwards in genetic improvement for grain yield. In fact, the least productive genotype (Don Sebastian) from the past three decades [7] was released in 2004, and regardless of growing conditions, in the current study it exhibited taller stature and lower HI than the most productive genotypes. Interestingly, the three least productive genotypes exhibited higher TKW and nitrogen concentration in kernels than the three most productive genotypes. This suggests that for some varieties grain quality has been a key breeding objective, even if this has been at the cost of lower yield. In fact, high TKW and $\mathrm{N}$ concentration in kernels are the two main quality traits in durum wheat [66].

A delay in leaf senescence (i.e. staygreen) would increase the amount of fixed carbon available for grain filling $[22,67,68]$. The positive effects of staygreen on yield have also been reported in other crops like sorghum [69] and maize [70]. However, in our study, the least productive cultivar, Don Sebastian, maintained a higher canopy green biomass during grain filling, assessed through different vegetation indices, as well as greener flag leaves during the last part of the grain filling period relative to the more productive cultivars. In the same sense, a negative relationship between a staygreen attitude and GY has been reported in rice [71]. In fact, because of the size of its flag leaf and low harvest index, Don Sebastian has a higher source of $\mathrm{N}$ for remobilization (large leaves; including the flag leaf) and a limited sink for $\mathrm{N}$ accumulation (low number of kernels per spike) compared to other cultivars (see also Sanchez-Bragado et al. [72]), which may contribute to delaying senescence [73-75].

In this study, $\delta^{13} \mathrm{C}_{\mathrm{kernel}}$ was negatively correlated with GY, not only across growing conditions, but also within each environment and across genotypes (Fig. 5). Negative correlations between $\delta^{13} C_{\text {kernel }}$ and grain yield across genotypes have been previously reported for durum wheat growing under a wide range of Mediterranean conditions, including different water, salinity or nitrogen fertilization conditions [28,76-79]. This negative association suggests that genotypes that can maintain higher water use and a greater stomatal conductance are the most 

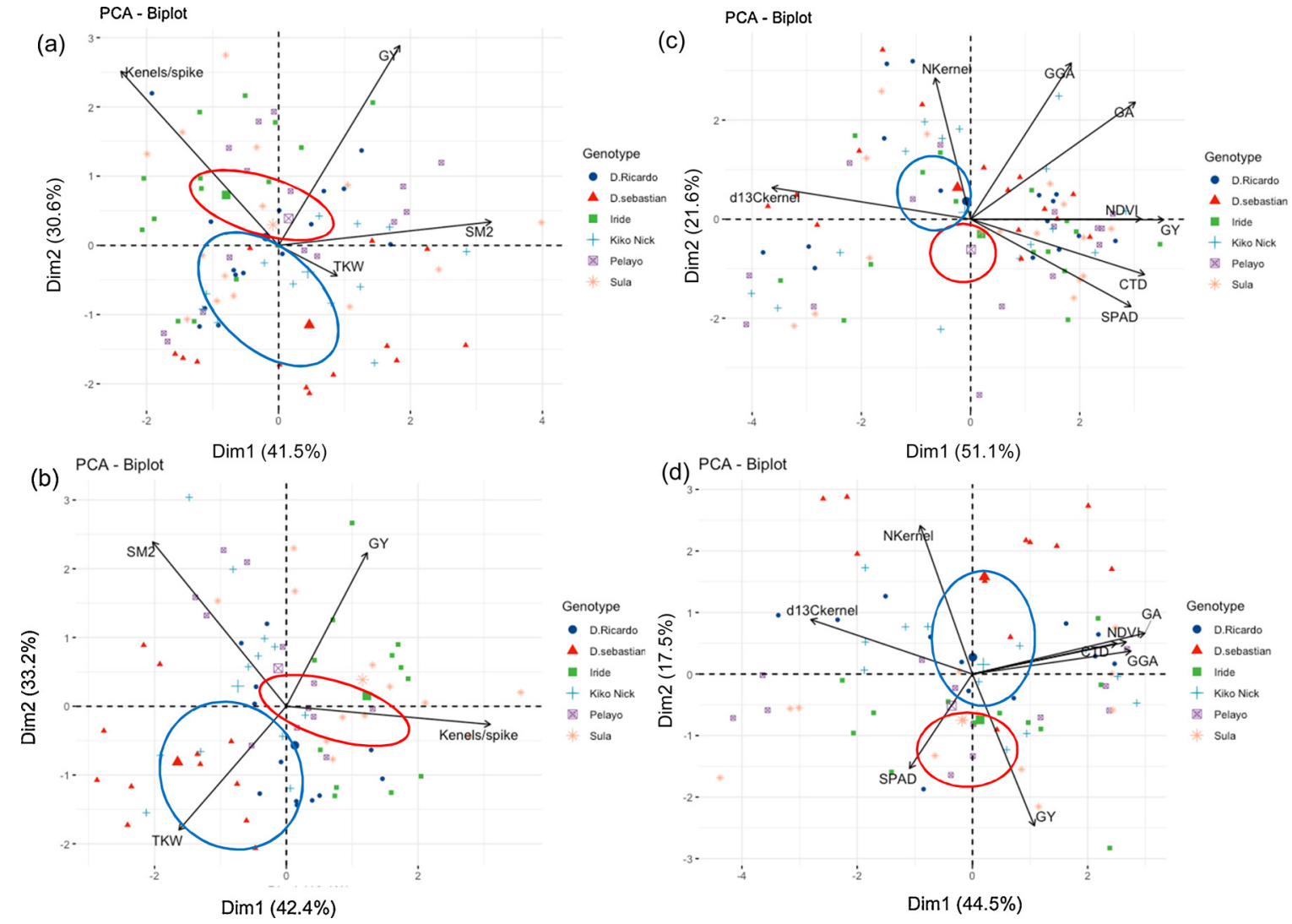

Fig. 7. The PCA of agronomic (a,b) and physiological (c,d) traits measured in six genotypes of wheat grown under low yielding (a,c) and high yielding (b,d) conditions in two growing seasons (2014 and 2015). Traits included in the PCA are: (a and b) grain yield (GY), kernels per spike (kernels spike ${ }^{-1}$ ), spikes $\mathrm{m}^{-2}$ (SM2) and thousand kernel weight (TKW); (c and d) grain yield (GY), chlorophyll content at grain filling (SPAD), carbon isotope composition ( $\delta^{13} \mathrm{Ckernel)}$, vegetation indices at grain filling (GA, GGA and NDVI), canopy temperature depression (CTD) and $\mathrm{N}$ content ( $\mathrm{N}_{\text {Kernel }}$ ).

productive [28,32]. Indeed, in this study Pelayo was the most productive genotype and exhibited the most negative $\delta^{13} \mathrm{C}_{\text {Kernels }}$ value alongside a cooler canopy compared with Don Sebastian. Despite the fact that no significant genotype by environment interaction was found for $\delta^{13} \mathrm{C}_{\text {Kernels, }}$, there was a trend towards a crossover in the graphic model of Finlay and Wilkinson [50] that placed this crossover in the most stressful growing conditions, was found. A negative interaction has been reported before [27,31,33,37] where a positive association between $\delta^{13} \mathrm{C}_{\text {Kernels }}$ and yield has been found under very dry Mediterranean rainfed conditions. Even so, a negative association is more common because genotypes capable of sustaining greater stomatal conductance and water consumption are more productive and better adapted. Differences in plant architecture may contribute, at least in part, to the differences in $\delta^{13} \mathrm{C}_{\text {Kernels }}$ across genotypes. Thus a large, prostrated, flag leaf, as in the case of Don Sebastian, Don Ricardo and Kiko Nick, may suffer water stress and then close its stomata earlier than genotypes with smaller and more erect flag leaves (Pelayo, Iride and Sula). In fact, we found a positive correlation between leaf length and $\delta^{13} \mathrm{C}_{\text {Kernels }}$ across genotypes. Moreover, visual observations suggested that flag leaves (and the rest of leaves in general) tended to be more erect in the most productive compared with the least productive genotypes. See the examples of Pelayo and Don Sebastian, the two extreme genotypes (Fig. 8). Leaf posture and area can affect the $\delta^{13} \mathrm{C}$, and indeed, Don Sebastian with its droopy leaves, together with its high $\delta^{13} \mathrm{C}$ and high canopy temperature suggests that it has a lower stomatal conductance [80] than Pelayo (Fig. 8).

To further understand the differences between the extreme genotypes in terms of grain yield and $\delta^{13} \mathrm{C}_{\text {Kernels, }}$, we analyzed $\delta^{13} \mathrm{C}$ from the dry matter and the water-soluble fractions of different photosynthetic tissues (including non-laminar parts) potentially contributing to filling the grains. While the genotype by environment interaction was not significant for $\delta^{13} \mathrm{C}_{\mathrm{kernel}}$, and only marginally significant for $\delta^{13} \mathrm{C}_{\text {leaf }}$, it achieved significance for the $\delta^{13} \mathrm{C}$ of different ear tissues. The presence of a genotype by environment interaction suggests genetic variance for plasticity for these traits [81]. The flag leaf exhibited much lower (i.e. negative) $\delta^{13} \mathrm{C}$ values than the mature kernels, the peduncle or other parts of the ear. Previous studies in durum and bread wheat $[35,77,82,83]$ and triticale [84] have found similar patterns of lower $\delta^{13} \mathrm{C}$ in the DM and the WSF of the flag leaves relative to different parts of the ears, while the mature kernels exhibited values between them but closer to the ear parts. Considering that no major fractionation occurs in the $\delta^{13} \mathrm{C}$ of the assimilates moving to the growing grains [34,35], which may otherwise affect the isotopic signature, these results suggest that the ear and plant parts other than the flag leaf have a key role in contributing to kernel growth $[34,35,77,83]$. The higher $\delta^{13} \mathrm{C}$ of the ear parts compared to the $\delta^{13} \mathrm{C}$ of the flag leaf is a constitutive fact (i.e. evidenced by the absence of stress) and can be attributed to the lower stomatal conductance of the ear tissues [83] together with their positioning in the upper part of the canopy, exposed to direct sunlight conditions. In fact, regardless of the growing conditions, ears exhibit a higher temperature than the leaves, even though the ear as a photosynthetic organ is more resistant to water stress than the flag leaf [85]. We tried to elucidate the relative importance of each organ as a photosynthetic contributor to grain filling through the relationship of their $\delta^{13} \mathrm{C}$ values with grain yield. The genotypic correlation of $\delta^{13} \mathrm{C}$ from the different plant parts against GY within each growing conditions was simply absent or much lower than the correlation between $\delta^{13} \mathrm{C}_{\text {kernels }}$ and GY. We gave more emphasis to the $\delta^{13} \mathrm{C}$ values of the WSF because this fraction represents the photoassimilates recently produced by the organs, while the $\delta^{13} \mathrm{C}$ signature analyzed in dry matter reflects the 

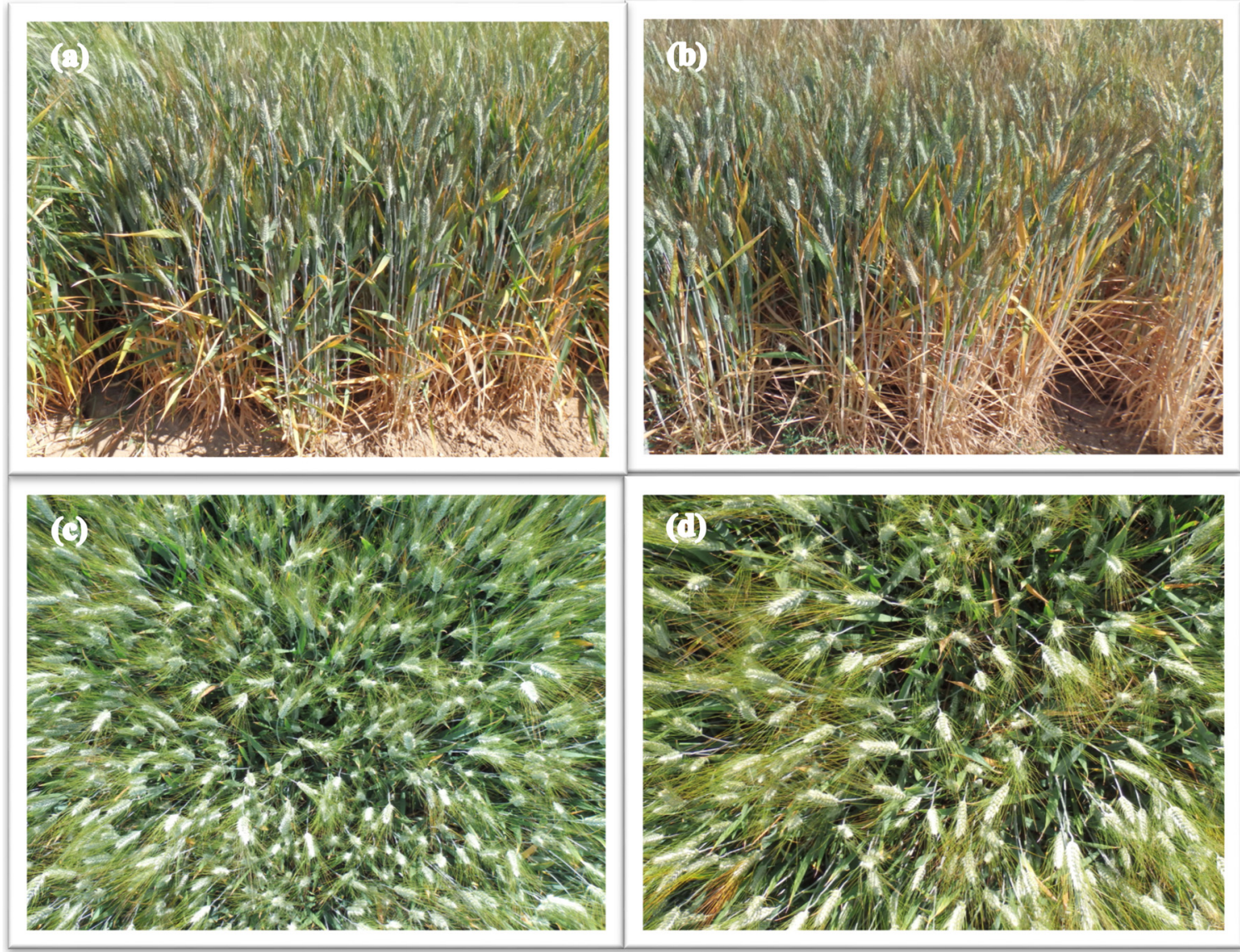

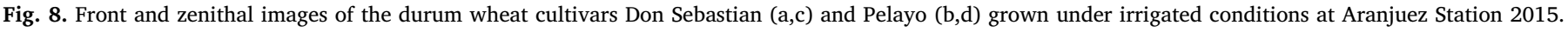

signature of the assimilates used during the growth of each organ [44]. In terms of WSF and for a couple of environments, some non-laminar organs correlated with GY. These results suggest that there is no specific plant part that accounts for the majority of the assimilates moving to the grains, but rather there are several contributors, which is also the case for the nitrogen [72]. Nonetheless, the $\delta^{13} \mathrm{C}$ in the WSF of the flag leaf did not correlate with any of the five growing conditions tested against grain yield or any of the two agronomic yield components defined during grain filling (TKW and kernels spike ${ }^{-1}$ ), which suggests that the role of the flag leaf as a photosynthetic organ during grain filling is minor. By contrast, the photosynthetic contribution of the nonlaminar parts to grain filling appears more important, considering the number of cases where a correlation with grain yield was found. The relationship between carbon isotope composition and agronomic yield components is poorly documented in durum wheat under Mediterranean conditions and usually is only addressed using the $\delta^{13} \mathrm{C}$ of kernels or leaves $[28,86]$. Some studies using different approaches have concluded that the major source of carbon assimilates for grain filling in cereals was the flag leaf [87]. However, more recent studies have revealed that, under post-anthesis water stress, ear photosynthesis plays a major role in grain filling $[34,35,85]$. In the present work, significant differences existed for the $\delta^{13} \mathrm{C}$ of different plant parts between the two extreme genotypes, but the photosynthetic tissue that exhibited the clearest difference between the two extreme genotypes was the palea for both DM and WSF, with the values in Pelayo being more negative than in Don Sebastian. Interestingly, and due to its position in the ear, the $\delta^{13} \mathrm{C}$ of the palea seems to originate from the refixation of $\mathrm{CO}_{2}$ respired by the grain rather than from assimilating atmospheric $\mathrm{CO}_{2}$ $[84,88]$. Thus, the $\delta^{13} \mathrm{C}$ of the palea exhibited the highest (least negative values), for both dry matter and the water-soluble fraction, compared to all the other plant parts. In fact, respired $\mathrm{CO}_{2}$ derived from the growing grains is re-fixed close to its site of evolution, and the palea is the closest ear tissue to the grains and the furthest from the atmospheric air. The hypothesis is that the highly productive genotype Pelayo takes advantage of the respired $\mathrm{CO}_{2}$ by re-fixing more of it than the least productive genotype Don Sebastian. Thus in Pelayo, the $\delta^{13} \mathrm{C}_{\text {palea }}$ in the water-soluble fraction was less negative than $\delta^{13} \mathrm{C}_{\text {kernel }}(2.75 \%$ less negative), however, in Don Sebastian $\delta^{13} \mathrm{C}_{\text {palea }}$ presented a similar value to $\delta^{13} \mathrm{C}_{\text {kernel }}(0.8 \%$ more negative).

\section{Conclusion}

In summary, the results of this study show that kernels spike ${ }^{-1}$ is the agronomic component most affected by the yield improvement of durum wheat cultivars released in Spain after the green revolution. This study has also identified a combination of characters that define an ideotype of durum wheat for the Mediterranean conditions of Spain. These genotypes should be characterized by a plant height of around $85 \mathrm{~cm}$ with a relatively small erect flag leaf, higher water use combined with a better water status (more negative $\delta^{13} \mathrm{C}_{\text {kernel }}$ and higher CTD), a better balance between the $\mathrm{N}$ source and $\mathrm{N}$ sink during grain filling (even if this does not translate to a staygreen attitude), and a higher capacity to re-fix $\mathrm{CO}_{2}$ respired by the grain. Also, it can be concluded that while the kernel is the most effective plant part for $\delta^{13} \mathrm{C}$ assessment in durum wheat under Mediterranean conditions, the non-laminar parts of the plants play a key role in providing assimilates during grain filling.

\section{Acknowledgements}

This study was supported by the Spanish project AGL2016-76527-R from MINECO, Spain. Fadia Chairi is the recipient of an FPI doctoral fellowship from the same institution. Jose Luis Araus acknowledges the 
support from the ICREA Academia of the Catalan Government, Spain.

\section{References}

[1] R. Ranieri, Geography of the Durum Wheat Crop, Pastaria Int., 2015 (Accessed September 8, 2017), https://scholar.google.com/scholar?q= Geography + of + the + durum + wheat + crop + ranieri\&btnG $=\& \mathrm{hl}=$ en\&as sdt $=0 \% 252 \mathrm{C} 5$.

[2] R. Taylor D, W.W. Koo, Outlook of the U.S. and World Wheat Industries, 2015 2024, 2015, (2015) https://ideas.repec.org/p/ags/nddaae/201310.html.

[3] C. Royo, Durum wheat improvement in Spain, in: C. Royo, M.M. Nachit, N. Di Fonzo, J.L. Araus, W.H. Pfeiffer, G.A. Slafer (Eds.), Durum Wheat Breeding: Current Approaches and Future Strategies, Food Products Press, New York, 2005, pp. 883-906, , https://doi.org/10.1007/s10535-006-0137-7.

[4] J. Juan-Aracil, A. Michelena, Durum wheat in Spain, in: N. Di Fonzo, F. Kaan, M. Nachit (Eds.), Durum wheat quality in the Mediterranean region, Zaragoza, CIHEAM,durum wheat q, 2019http://ressources.ciheam.org/om/pdf/a22/ 95605360.pdf (Accessed April 28, 2019).

[5] K.A.B. Aisawi, M.P. Reynolds, R.P. Singh, M.J. Foulkes, The physiological basis of the genetic progress in yield potential of CIMMYT spring wheat cultivars from 1966 to 2009 , Crop Sci. 55 (2015) 1749-1764, https://doi.org/10.2135/cropsci2014.09. 0601.

[6] P. De Vita, O.L.D. Nicosia, F. Nigro, C. Platani, C. Riefolo, N. Di Fonzo, L. Cattivelli, Breeding progress in morpho-physiological, agronomical and qualitative traits of durum wheat cultivars released in Italy during the 20th century, Eur. J. Agron. 26 (2007) 39-53, https://doi.org/10.1016/j.eja.2006.08.009.

[7] F. Chairi, O. Vergara-Diaz, T. Vatter, N. Aparicio, M.T. Nieto-Taladriz, S.C. Kefauver, J. Bort, M.D. Serret, J.L. Araus, Post-green revolution genetic advance in durum wheat: the case of Spain, Field Crop. Res. 228 (2018) 158-169, https://doi.org/10.1016/j.fcr.2018.09.003.

[8] C. Royo, V. Martos, A. Ramdani, D. Villegas, Y. Rharrabti, L.F. García Del Moral, Changes in yield and carbon isotope discrimination of Italian and Spanish durum wheat during the 20th century, Agron. J. 100 (2008) 352-360, https://doi.org/10. 2134/agronj2007.0060.

[9] M. Sanchez-Garcia, C. Royo, N. Aparicio, J.A. Martín-Sánchez, F. Álvaro, Genetic improvement of bread wheat yield and associated traits in Spain during the 20th century, J. Agric. Sci. 151 (2012) 105-118, https://doi.org/10.1017/ S0021859612000330.

[10] M. Acreche, G. Brice, J.A. Mart, G.A. Slafer, Physiological bases of genetic gains in Mediterranean bread wheat yield in Spain, Eur. J. Agron. 28 (2008) 162-170, https://doi.org/10.1016/j.eja.2007.07.001.

[11] C. Royo, F. Álvaro, V. Martos, A. Ramdani, J. Isidro, D. Villegas, L.F. García del Moral, Genetic changes in durum wheat yield components and associated traits in Italian and Spanish varieties during the 20th century, Euphytica 155 (2007) 259-270, https://doi.org/10.1007/s10681-006-9327-9.

[12] R. Fischer, Y. Stockman, Increased kernel number in Norin 10-derived dwarf wheat: Evaluation of the c Kernel Number in Norin 10-Derived Dwarf Wheat: Evaluation of the Cause, Aust. J. Plant Physiol. 13 (1986) 767, https://doi.org/10.1071/ PP9860767.

[13] D.J. Miralles, G.A. Slafer, Yield, biomass and yield components in dwarf, semi-dwarf and tall isogenic lines of spring wheat under recommended and late sowing dates, Plant Breed. 114 (1995) 392-396, https://doi.org/10.1111/j.1439-0523. 1995.tb00818.x.

[14] R.A. Richards, The effect of dwarfing genes in spring wheat in dry environments. I. Agronomic characteristics, Aust. J. Agric. Res. 43 (1992) 517-527, https://doi.org/ 10.1071/AR9920517.

[15] F. Giunta, R. Motzo, G. Pruneddu, Trends since 1900 in the yield potential of Italian-bred durum wheat cultivars, Eur. J. Agron. 27 (2007) 12-24, https://doi. org/10.1016/j.eja.2007.01.009.

[16] M.J. Foulkes, J.W. Snape, V.J. Sherman, M.P. Reynolds, O. Gaju, R. SylvesterBradely, Genetic progress in yield potential in wheat: recent advances and future prospects, J. Agric. Sci. 145 (2007) 17-29, https://doi.org/10.1017/ s0021859607006740.

[17] G.J. Rebetzke, T.C. Scientific, R. Richards, T.C. Scientific, G.D. Farquhar, Selection for Reduced Carbon Isotope Discrimination Increases Aerial Biomass and Grain Yield of Rainfed Bread Wheat G. (2002), pp. 739-745, https://doi.org/10.2135/ cropsci2002.0739.

[18] M. Reynolds, F. Dreccer, R. Trethowan, Drought-adaptive traits derived from wheat wild relatives and landraces, J. Exp. Bot. 58 (2006) 177-186, https://doi.org/10. 1093/jxb/erl250.

[19] J.L. Araus, G.A. Slafer, C. Royo, M.D. Serret, Breeding for yield potential and stress adaptation in cereals, Crit. Rev. Plant Sci. 27 (2008) 377-412, https://doi.org/10. 1080/07352680802467736.

[20] E.A. Tambussi, J. Bort, J.L. Araus, Water use efficiency in C3 cereals under Mediterranean conditions: a review of physiological aspects, Ann. Appl. Biol. 150 (2007) 307-321, https://doi.org/10.1111/j.1744-7348.2007.00143.x.

[21] M.S. Lopes, M.P. Reynolds, Stay-green in spring wheat can be determined by spectral reflectance measurements (normalized difference vegetation index) independently from phenology, J. Exp. Bot. 63 (2012) 3789-3798, https://doi.org/ 10.1093/jxb/ers071.

[22] E. Carmo-Silva, P.J. Andralojc, J.C. Scales, S.M. Driever, A. Mead, T. Lawson, C.A. Raines, M.A.J. Parry, Phenotyping of field-grown wheat in the UK highlights contribution of light response of photosynthesis and flag leaf longevity to grain yield, J. Exp. Bot. 68 (2017) 3473-3486, https://doi.org/10.1093/jxb/erx169.

[23] K. Vijayalakshmi, A.K. Fritz, G.M. Paulsen, G. Bai, S. Pandravada, B.S. Gill, Modeling and mapping QTL for senescence-related traits in winter wheat under high temperature, Mol. Breed. 26 (2010) 163-175, https://doi.org/10.1007/ s11032-009-9366-8.

[24] M.J. Hawkesford, J.L. Araus, R. Park, D. Calderini, D. Miralles, T. Shen, J. Zhang, M.A.J. Parry, Prospects of doubling global wheat yields, Food Energy Secur. 2 (2013) 34-48, https://doi.org/10.1002/fes3.15.

[25] R.A. Fischer, D. Rees, K.D. Sayre, Z.M. Lu, A.G. Condon, A. Larque Saavedra, Whea yield progress associated with higher stomatal conductance and photosynthetic rate, and cooler canopies, Crop Sci. 38 (1998) 1467-1475, https://doi.org/10. 2135/cropsci1998.0011183X003800060011x.

[26] D. Roche, Stomatal conductance is essential for higher yield potential of C 3 crops, Crit. Rev. Plant Sci. 34 (2015) 429-453, https://doi.org/10.1080/07352689.2015. 1023677.

[27] J.L. Araus, L. Cabrera-Bosquet, M.D. Serret, J. Bort, M.T. Nieto-Taladriz Comparative performance of $\delta 13 \mathrm{C}, \delta 18 \mathrm{O}$ and $\delta^{15} \mathrm{~N}$ for phenotyping durum wheat adaptation to a dryland environment, Funct. Plant Biol. 40 (2013) 595-608, https://doi.org/10.1071/FP12254.

[28] J.L. Araus, D. Villegas, N. Aparicio, L.F.G. del Moral, S. El Hani, Y. Rharrabti, J.P.P. Ferrio, C. Royo, L.F. Garcia del Moral, S. El Hani, Y. Rharrabti, J.P.P. Ferrio, C. Royo, Environmental factors determining carbon isotope discrimination and yield in durum wheat under Mediterranean conditions, Crop Sci. 43 (2003) 170-180, https://doi.org/10.2135/cropsci2003.1700.

[29] M. Hafsi, P. Monneveux, O. Merah, A. Djekoune, C. Royo, M.M. Nachit, N. Di Fonzo, J.L. Araus, Carbon isotope discrimination and yield in durum wheat grown in the high plains of Setif (Algeria). Contribution of different organs to grain filling, Durum Wheat Improv. Mediterr. Reg. New Challenges. 40 (32676BC) Spain, 12Spain, (2019), p. 14 (Accessed October 12, 2017), http://om.ciheam.org/article. php?IDPDF $=600020$ http://www.ciheam.org/.

[30] R.A. Richards, G.J. Rebetzke, A.G. Condon, A.F. Van Herwaarden, Breeding opportunities for increasing the efficiency of water use and crop yield in temperate cereals, Crop Sci. 42 (2002) 111-121, https://doi.org/10.2135/cropsci2002.0111.

[31] A.G. Condon, R.A. Richards, G.D. Farquhar, Carbon isotope discrimination is positively correlated with grain yield and dry matter production in field-grown Wheat1, Crop Sci. 27 (1987) 996, https://doi.org/10.2135/cropsci1987. 0011183X002700050035x.

[32] A. Blum, Effective use of water (EUW) and not water-use efficiency (WUE) is the target of crop yield improvement under drought stress, Field Crop. Res. 112 (2009) 119-123, https://doi.org/10.1016/j.fcr.2009.03.009.

[33] A. Elazab, J. Bort, B. Zhou, M.D. Serret, M.T. Nieto-Taladriz, J.L. Araus, The combined use of vegetation indices and stable isotopes to predict durum wheat grain yield under contrasting water conditions, Agric. Water Manag. 158 (2015) 196-208, https://doi.org/10.1016/j.agwat.2015.05.003.

[34] R. Sanchez-Bragado, A. Elazab, B. Zhou, M.D. Serret, J. Bort, M.T. Nieto-Taladriz, J.L. Araus, Contribution of the ear and the flag leaf to grain filling in durum whea inferred from the carbon isotope signature: genotypic and growing conditions effects, J. Integr. Plant Biol. 56 (2014) 444-454, https://doi.org/10.1111/jipb. 12106.

[35] R. Sanchez-Bragado, G. Molero, M.P. Reynolds, J.L. Araus, Photosynthetic contribution of the ear to grain filling in wheat: a comparison of different methodologies for evaluation, J. Exp. Bot. 67 (2016) 2787-2798, https://doi.org/10.1093/ jxb/erw116.

[36] O. Merah, P. Monneveux, Contribution of different organs to grain filling in durum wheat under mediterranean conditions I. Contribution of post-anthesis photosynthesis and remobilization, J. Agron. Crop Sci. 201 (2015) 344-352, https://doi. org/10.1111/jac.12109.

[37] S. Medina, R. Vicente, M.T. Nieto-Taladriz, N. Aparicio, F. Chairi, O. Vergara-Diaz, J.L. Araus, The plant-transpiration response to vapor pressure deficit (VPD) in durum wheat is associated with differential yield performance and specific expression of genes involved in primary metabolism and water transport, Front. Plan Sci. 9 (2019) 1-19, https://doi.org/10.3389/fpls.2018.01994.

[38] J.C. Zadoks, T.T. Chang, C.F. Konzak, A decimal code for the growth stages of cereals, Weed Res. 14 (1974) 415-421, https://doi.org/10.1111/j.1365-3180.1974 tb01084.x.

[39] J. Casadesús, Y. Kaya, J. Bort, M.M. Nachit, J.L. Araus, S. Amor, G. Ferrazzano, F. Maalouf, M. Maccaferri, V. Martos, H. Ouabbou, D. Villegas, M. Maccaferri, J. Bort, S. Amor, Using vegetation indices derived from conventional digital cameras as selection criteria for wheat breeding in water-limited environments, Ann. Appl. Biol. 150 (2007) 227-236, https://doi.org/10.1111/j.1744-7348.2007. 00116.x.

[40] T.B. Coplen, Explanatory Glossary of Terms Used in Expression of Relative Isotope Ratios and Gas Ratios. IUPAC Recommendations 2008. (International Union of Pure and Applied Chemistry Inorganic Chemistry Division, Commission on Isotopic Abundances and Atomic Weights: Research Triangle Park, NC, USA), Canada Austria China/Beijing); Natl. Represent. J. R. Laeter (Australia, (2008) (Accessed November 28, 2017), http://old.iupac.org/reports/provisional/abstract08/coplen. prs.pdf.

[41] G.D. Farquhar, J.R. Ehleringer, K.T. Hubick, Carbon isotope discrimination and photosynthesis, Annu. Rev. Plant Physiol. Plant Mol. Biol. 40 (1989) 503-537, https://doi.org/10.1146/annurev.pp.40.060189.002443.

[42] L. Cabrera-Bosquet, R. Albrizio, S. Nogués, J.L. Araus, Dual $\Delta^{13} \mathrm{C} / \delta^{18} \mathrm{O}$ response to water and nitrogen availability and its relationship with yield in field-grown durum wheat, Plant Cell Environ. 34 (2011) 418-433, https://doi.org/10.1111/j.13653040.2010.02252.x.

[43] R. Sanchez-Bragado, G. Molero, M.P. Reynolds, J.L. Araus, Relative contribution of shoot and ear photosynthesis to grain filling in wheat under good agronomical conditions assessed by differential organ $\delta^{13} \mathrm{C}$, J. Exp. Bot. 65 (2014) 5401-5413, https://doi.org/10.1093/jxb/eru298. 
[44] S. Yousfi, M.D. Serret, J.L. Araus, Comparative response of $\delta 13 \mathrm{C}, \delta 180$ and $\delta^{15} \mathrm{~N}$ in durum wheat exposed to salinity at the vegetative and reproductive stages, Plant, Cell Environ. 36 (2013) 1214-1227, https://doi.org/10.1111/pce.12055.

[45] W. Yan, M.S. Kang, GGE Biplot Analysis, CRC Press, 2002, https://doi.org/10. 1201/9781420040371.

[46] A. Pacheco, M. Vargas, G. Alvarado, F. Rodríguez, GEA-R (Genotype Environment Analysis With R for Windows) Version 4.0. CIMMYT, (2015) (Accessed May 22, 2019), https://scholar.google.es/scholar? cluster $=8720594121169897844 \& \mathrm{hl}=\mathrm{es}$ \&as sdt $=2005 \&$ sciodt $=0,5 \&$ scioq $=$ GEA-R + analysis + genotype + by + environment.

[47] J.P. Pennacchi, E. Carmo-Silva, P.J. Andralojc, T. Lawson, A.M. Allen, C.A. Raines, M.A.J. Parry, Stability of wheat grain yields over three field seasons in the UK, Food Energy Secur. (2018), https://doi.org/10.1002/fes3.147.

[48] R.A. Fischer, G.O. Edmeades, Breeding and cereal yield progress, Crop Sci. (2010), https://doi.org/10.2135/cropsci2009.10.0564.

[49] K.P. Voss-Fels, A. Stahl, B. Wittkop, C. Lichthardt, S. Nagler, T. Rose, T.-W. Chen, H. Zetzsche, S. Seddig, M. Majid Baig, A. Ballvora, M. Frisch, E. Ross, B.J. Hayes, M.J. Hayden, F. Ordon, J. Leon, H. Kage, W. Friedt, H. Stützel, R.J. Snowdon, Breeding improves wheat productivity under contrasting agrochemical input levels, Nat. Plants (2019), https://doi.org/10.1038/s41477-019-0445-5.

[50] K.W. Finlay, G.N. Wilkinson, The analysis of adaptation in a plant-breeding programme, Aust. J. Agric. Res. 14 (1963) 742-754, https://doi.org/10.1071/ AR9630742.

[51] E. Acevedo, Potential of carbon isotope discrimination as a selection criterion in Barley Breeding, stable isot, Plant Carbon-Water Relations (1993) 399-417, https://doi.org/10.1016/B978-0-08-091801-3.50035-0.

[52] P. Annicchiarico, L. Pecetti, Yield vs. Morphophysiological trait-based criteria for selection of durum wheat in a semi-arid Mediterranean region (northern Syria), $\mathrm{F}$. Crop. Res. 59 (1998) 163-173, https://doi.org/10.1016/S0378-4290(98)00116-6.

[53] R.B. Austin, J. Bingham, R.D. Blackwell, L.T. Evans, M.A. Ford, C.L. Morgan, M. Taylor, Genetic improvements in winter wheat yields since 1900 and associated physiological changes, J. Agric. Sci. 94 (1980) 675, https://doi.org/10.1017/ S0021859600028665.

[54] K.D. Sayre, S. Rajaram, R.A. Fischer, Yield potential progress in short bread wheats in northwest Mexico, Crop Sci. 37 (1997) 36-42, https://doi.org/10.2135/ cropsci1997.0011183X003700010006x.

55] D.F. Calderini, M.F. Dreccer, G.A. Slafer, Genetic improvement in wheat yield and associated traits. A re-examination of previous results and the latest trends, Plant Breed. 114 (1995) 108-112, https://doi.org/10.1111/j.1439-0523.1995 tb00772.x.

[56] M.J. Foulkes, G.A. Slafer, W.J. Davies, P.M. Berry, R. Sylvester-Bradley, P. Martre, D.F. Calderini, S. Griffiths, M.P. Reynolds, Raising yield potential of wheat. III. Optimizing partitioning to grain while maintaining lodging resistance, J. Exp. Bot. 62 (2011) 469-486, https://doi.org/10.1093/jxb/erq300.

[57] A. Del Pozo, I. Matus, M.D. Serret, J.L. Araus, Agronomic and physiological traits associated with breeding advances of wheat under high-productive Mediterranean conditions. The case of Chile, Environ. Exp. Bot. 103 (2014) 180-189, https://doi. org/10.1016/j.envexpbot.2013.09.016.

[58] V.J. Shearman, R.K. Scott, M.J. Foulkes, Crop Physiology and Metabolism. Physiological Processes Associated with Wheat Yield Progress in the UK, Crop Sci. 185 (2005) 175-185, https://doi.org/10.2135/cropsci2005.0175.

[59] G.A. Slafer, D.F. Calderini, D.J. Miralles, Yield Components and Compensation in Wheat: Opportunities for Further Increasing Yield Potential, (1996) (Accessed April 23, 2019), http://agris.fao.org/agris-search/search.do?recordID = QY9700152.

[60] G.A. Slafer, R. Savin, V.O. Sadras, Coarse and fine regulation of wheat yield components in response to genotype and environment, Field Crop. Res. 157 (2014) 71-83, https://doi.org/10.1016/J.FCR.2013.12.004.

[61] M.J. Foulkes, M.P. Reynolds, R. Sylvester-Bradley, Genetic Improvement of Grain Crops, Crop Physiol., 2009, pp. 355-385, https://doi.org/10.1016/b978-0-12374431-9.00015-3.

[62] G.A. Slafer, F.H. Andrade, Genetic improvement in bread wheat (Triticum aestivum) yield in Argentina, F. Crop. Res. Elsevier Sci. Publ. B.V. 21 (1989) 289-296, https://doi.org/10.1016/0378-4290(89)90010-5.

[63] G.A. García, A.K. Hasan, L.E. Puhl, M.P. Reynolds, D.F. Calderini, D.J. Miralles, Grain yield potential strategies in an elite wheat double-haploid population grown in contrasting environments, Crop Sci. 53 (2013) 2577, https://doi.org/10.2135/ cropsci2012.11.0669.

[64] S. Denčić, R. Kastori, B. Kobiljski, B. Duggan, Evaluation of grain yield and its components in wheat cultivars and landraces under near optimal and drought conditions, Euphytica 113 (2000) 43-52, https://doi.org/10.1023/ A:1003997700865.

[65] G.A. Slafer, J.L. Araus, C. Royo, L.F. García, D. Moral, Promising Eco-physiological Traits for Genetic Improvement of Cereal Yields in Mediterranean Environments, (2005) https://www.ugr.es/ Ifgm/images/Slafer et al. 2005.pdf (Accessed December 19, 2018).

[66] C. Royo, G.A. Briceño-Félix, Spanish wheat pool, J. Chem. Inf. Model. (2013) 1689-1699, https://doi.org/10.1017/СBO9781107415324.004.
[67] A. del Pozo, A. Yáñez, I.A. Matus, G. Tapia, D. Castillo, L. Sanchez-Jardón, J.L. Araus, Physiological traits associated with wheat yield potential and performance under water-stress in a mediterranean environment, Front. Plant Sci. 7 (2016), https://doi.org/10.3389/fpls.2016.00987.

[68] M. Bogard, M. Jourdan, V. Allard, P. Martre, M.R. Perretant, C. Ravel, E. Heumez, S. Orford, J. Snape, S. Griffiths, O. Gaju, J. Foulkes, J. Le Gouis, Anthesis date mainly explained correlations between post-anthesis leaf senescence, grain yield, and grain protein concentration in a winter wheat population segregating for flowering time QTLs, J. Exp. Bot. 62 (2011) 3621-3636, https://doi.org/10.1093/ jxb/err061.

[69] A.K. Borrell, G.L. Hammer, A.C.L. Douglas, Does maintaining green leaf area in sorghum improve yield under drought? I. Leaf growth and senescence, Crop Sci. 40 (2000) 1026-1037, https://doi.org/10.2135/cropsci2000.4041026x.

[70] E.A. Lee, M. Tollenaar, Physiological basis of successful breeding strategies for maize grain yield, Crop Sci. 47 (2007), https://doi.org/10.2135/cropsci2007.04. 0010IPBS.

[71] G.H. Jiang, Y.Q. He, C.G. Xu, X.H. Li, Q. Zhang, The genetic basis of stay-green in rice analyzed in a population of doubled haploid lines derived from an indica by japonica cross, Theor. Appl. Genet. 108 (2004) 688-698, https://doi.org/10.1007/ s00122-003-1465-z.

[72] R. Sanchez-Bragado, M.D. Serret, J.L. Araus, The nitrogen contribution of different plant parts to wheat grains: exploring genotype, water, and nitrogen effects, Front Plant Sci. 7 (2017), https://doi.org/10.3389/fpls.2016.01986.

[73] L. Borrás, G.A. Slafer, M.E. Otegui, Seed dry weight response to source-sink manipulations in wheat, maize and soybean: a quantitative reappraisal, Field Crop. Res. 86 (2004) 131-146, https://doi.org/10.1016/j.fcr.2003.08.002.

[74] I. Rajcan, M. Tollenaar, Source: sink ratio and leaf senescence in maize: II. Nitrogen metabolism during grain filling, F. Crop. Res. 60 (1999) 255-265, https://doi.org/ 10.1016/S0378-4290(98)00143-9.

[75] I. Rajcan, M. Tollenaar, Source : sink ratio and leaf senescence in maize:: I. Dry matter accumulation and partitioning during grain filling, FieldCrop. Res. 60 (1999) 245-253, https://doi.org/10.1016/S0378-4290(98)00142-7.

[76] J. Bort, M. Belhaj, K. Latiri, Z. Kehel, J.L. Araus, Comparative performance of the stable isotope signatures of carbon, nitrogen and oxygen in assessing early vigour and grain yield in durum wheat, J. Agric. Sci. 152 (2014) 408-426, https://doi.org/ 10.1017/S0021859613000269.

[77] O. Merah, E. Deléens, B. Teulat, P. Monneveux, Association between yield and carbon isotope discrimination value in different organs of durum wheat under drought, J. Agron. Crop Sci. 188 (2002) 426-434, https://doi.org/10.1046/j.1439037X.2002.00594.X.

[78] P. Monneveux, D. Rekika, E. Acevedo, O. Merah, Effect of drought on leaf gas exchange, carbon isotope discrimination, transpiration efficiency and productivity in field grown durum wheat genotypes, Plant Sci. 170 (2006) 867-872, https://doi. org/10.1016/j.plantsci.2005.12.008.

[79] Z. Chamekh, S. Ayadi, C. Karmous, Y. Trifa, H. Amara, K. Boudabbous, S. Yousfi, M. Dolors Serret, J.L. Araus, Comparative effect of salinity on growth, grain yield water use efficiency, $\delta 13 \mathrm{C}$ and $\delta^{15} \mathrm{~N}$ of landraces and improved durum wheat varieties, (2016), https://doi.org/10.1016/j.plantsci.2016.07.005.

[80] J.L. Araus, M.P. Reynolds, E. Acevedo, Leaf posture, grain yield, growth, leaf structure, and carbon isotope discrimination in wheat, Crop Sci. 33 (1993) 1273, https://doi.org/10.2135/cropsci1993.0011183X003300060032x.

[81] C.D. Schlichting, The evolution of phenotypic plasticity in plants, Annu. Rev. Ecol Syst. 17 (1986) 667-693, https://doi.org/10.1146/annurev.es.17.110186.003315

[82] B. Zhou, Á. Sanz-Sáez, A. Elazab, T. Shen, R. Sánchez-Bragado, J. Bort, M.D. Serret, J.L. Araus, Physiological traits contributed to the recent increase in yield potential of winter wheat from Henan Province, China, J. Integr. Plant Biol. 56 (2014) 492-504, https://doi.org/10.1111/jipb.12148.

[83] J.L. Araus, H.R. Brown, A. Febrero, J. Bort, M.D. Serret, Ear photosynthesis, carbon isotope discrimination and the contribution of respiratory $\mathrm{CO}_{2}$ to differences in grain mass in durum wheat, Plant Cell Environ. 16 (1993) 383-392, https://doi org/10.1111/j.1365-3040.1993.tb00884.x.

[84] J.L. Araus, P. Santiveri, D. Bosch-Serra, C. Royo, I. Romagosa, Carbon isotope ratios in ear parts of triticale : influence of grain filling, Plant Physiol. 100 (1992) 1033-1035 (Accessed April 27, 2019), http://www.ncbi.nlm.nih.gov/pubmed/ 16653012.

[85] R. Vicente, O. Vergara-Diaz, S. Medina, F. Chairi, S.C. Kefauver, J. Bort, M.D. Serret, N. Aparicio, J.L. Araus, Title : Differential Physiological and Gene Expression Responses of Durum Wheat Leaves and Ears to Contrasting Water Regimes, (2017), pp. $1-37$

[86] I.F. Wardlaw, The control of carbon partitioning in plants, New Phytol. 116 (1990) 341-381, https://doi.org/10.1108/08880451111169124.

[87] O. Merah, E. Deléens, P. Monneveux, Relationships between carbon isotope discrimination, dry matter production, and harvest index in durum wheat, J. Plant Physiol. 158 (2001) 723-729, https://doi.org/10.1078/0176-1617-00273.

[88] J. Bort, R.H. Brown, J.L. Araus, Refixation of respiratory $\mathrm{CO}_{2}$ in the ears of $\mathrm{C} 3$ cereals, J. Exp. Bot. 47 (2007) 1567-1575, https://doi.org/10.1093/jxb/47.10. 1567. 